\title{
Kaswutarha - hyötyä, huwitusta ja siweyden tuntoa
}

\author{
Puutarhanhoito kansan kasvattajana 1860-1930-lukujen puutarhakirjoissa
}

\author{
Marjukka Piirainen
}

\begin{abstract}
Kaswutarhan ${ }^{2}$ wiljelyksen hyöty kansalle on yleisesti myönnetty ja tunnustettu. Oikein menetettynä tuottaapi se wiljeliällensä etua ja woittoa taloudessansa. Sitten on se wielä suuressa arwossa maalliselle ja hengelliselle siweydellemme. Muutamat sen tuotteet, niinkuin ruokakaswut, owat terweydellemme hyödylliset sillä tawoin että oikein käytettynä edistäwät ruuan sulamista. Toiset taas, niinkuin hedelmäpuut tuottawat hyötyä sekä huwitusta hedelmillänsä, kukostuksillansa ja wiheriöimällänsä. Kukkaiset tosin owat meille ainoastaan huwiksi kauniilla wäreillänsä ja ihanalla kaswannollaan; mutta on niitä huwituksia, jotka siwistäwät ihmistä ja niihin huwituksiin luemme kukkien seuranpidon. (Eneroth 1860, Alku-lause.) ${ }^{3}$
\end{abstract}

Yllä oleva ote on peräisin ensimmäisestä suomen kielellä julkaistusta puutarhakirjasta, vuonna 1860 ilmestyneestä teoksesta Kaswutarha-kirja Rahwaan hyödyksi. Kirjaan perehtyminen vaatii nykylukijalta hieman totuttelua, sillä teksti on kirjoitettu fraktuuralla, kasvien nimet poikkeavat nykyisistä eikä sanasto välttämättä avaudu heti. ${ }^{4}$ Asiasisältö on kuitenkin edelleen pätevää ja kirjassa esitelty kasvivalikoima monipuolinen. Käytettävissäni olevan Kaswutarha-kirjan sisäkannessa on ote Kaawin Lainakirjaston säännöistä, joten kirja on ollut käytössä 1800-luvun jälkipuoliskolla Pohjois-Savossa. ${ }^{5}$ Se on ollut varsin laajalle levinnyt teos, sillä se kuului 1870 -luvulla myös useiden muiden kirjastojen kokoelmiin ${ }^{6}$ ja oli mukana kansakoulujen kirjastosuosituksissa (Keldán 1871, 14). Vuonna 1883 Kaswutarha-kirjaa oletettavasti sen tuona vuonna ilmestynyttä toista painosta - jaettiin ilmaiseksi Sanomia Turusta -lehden tilaajille (Kivistö 2013, 540).

Artikkeli on kirjoitettu Suomen Kulttuurirahaston päärahaston (2014) ja Kainuun rahaston (2018) apurahoilla.

Puutarha-alan sanasto oli vakiintumatonta pitkälle 1900-luvulle saakka. Yleisin nykyistä puutarhaa tarkoittanut ilmaus vanhoissa puutarhakirjoissa oli kasvitarha, jonka merkitys kuitenkin vaihteli vihannesmaasta koko puutarhaan hedelmäpuineen ja marjapensaineen sekä koristekasveineen. Tässä artikkelissa käyttämäni sana puutarha sisältää kaikki edellä mainitut erilaisina yhdistelminä. (Ks. Simonen 1961, 185.)

Kiitän Antti Niemeläistä, jonka puutarhakirjakokoelmastaan käyttööni luovuttamat teokset toimivat tämän tutkimuksen alkusysäyksenä ja ovat muodostaneet merkittävän osan tutkimusaineistosta.

4 Esimerkiksi Räätikäs, Morintteri, Matelewa pöönä, Eternelli ja Tielytra, eli lanttu, porkkana, pensaspapu, ikikukka ja särkynytsydän; wesiruoste eli happo = pohjavesi, tehdas = istutuspenkki, guano = lannoitusaineena käytetty merilintujen tai lepakoiden uloste.

5 Kaavin lainakirjastosta esim. Kuopion Hippakunnan Sanomia no 20, 12.11.1859.

6 Ks. esim. Luettelo Kuopion kaupungin kansankirjaston kirjoista 1873, s. 3; Luettelo Rauman lainakirjaston kirjoista 1873, 6). 
Kaswutarha-kirja on käännös ruotsinkielisestä alkuteoksesta Trädgårdsbok för Allmogen (1857) ${ }^{7}$, jonka kirjoittaja on Ruotsin puutarhaviljelyn uranuurtaja Olof Eneroth (1825-1881). Hän perustelee esipuheessa puutarhaviljelyn hyötyä kansalle monin tavoin. Huomiota kiinnittävät erityisesti Enerothin maininnat sivistyksestä ja siveydestä: kasvitarhanhoito on eduksi maalliselle ja hengelliselle siveydelle, kukat ovat huvituksia, jotka sivistävät ihmistä ja puutarhatyö herättää ja kasvattaa siveyden ja järjestyksen, kauneuden ja ihanuuden tuntoa. Mitä Eneroth tarkoittaa ja mitä tekemistä puutarhanhoidolla on siveyden ja sivistyksen kanssa?

Kaswutarha-kirjan ilmestyessä oli puutarhanhoitoa harjoitettu jo satojen vuosien ajan Etelä- ja Lounais-Suomen kartanoissa, joissa oli vihannesmaiden ja hedelmätarhojen lisäksi koristepuutarhoja, kasvihuoneita ja laajoja puistoalueita. Suomen vanhimmilla kulttuurialueilla puutarhakasveja viljeltiin kaupungeissa ja myös rahvaan keskuudessa maaseudulla jo 1700-luvulla ja 1800-luvun alussa. 1800-luvun aikana perustettiin erilaisia puutarhayhdistyksiä, neuvontatoiminta virisi ja ensimmäiset puutarhaopetusta antaneet oppilaitokset perustettiin. Toiminnan pääpaino oli kuitenkin maan eteläisissä osissa. Puutarhakulttuuria tekivät alueellisesti laajemmin tunnetuksi ruukit ja muut teollisuuslaitokset, rautatieasemien ja kanavien istutukset, kaupunkipuistot ja etenkin pappilat. (Alanko 2018; Häyrynen ym. 2001; Ruoff 2001a; Simonen 1961; Halme 2005; Koskimies 2009; Martin 2016; Koskimies ja Knuuttila 2007.) Kotipuutarhaviljely levisi silti kansan pariin hitaasti, sillä rahvaan keskuudessa sekä puutarhan hyöty- että koristekasvit olivat vielä 1920-luvulla monin paikoin lähes tuntemattomia etenkin maan pohjoisosissa (Parvela 1930, esim. 67, 142-150, 178-192, 201). Kansaa moitittiinkin sekä puutarhakirjoissa että yleensä maataloutta ja puutarhaviljelyä koskevassa keskustelussa takapajuisuudesta, tietämättömyydestä ja haluttomuudesta omaksua uusia tapoja (ks. esim. Kaarlenkaski ja Piirainen 2014, 9-11; Donner 2015, 83, 109-110).

Tarkastelen tässä artikkelissa suomenkieliselle valtaväestölle, "kansalle", ${ }^{8}$ suunnatun puutarhavalistuksen sisältöä vanhojen puutarhakirjojen avulla. Tutkimusaineistonani on 40 suomenkielistä puutarhakirjaa, jotka on julkaistu 1860-1930-luvuilla. Tutkimuksen aikarajaus perustuu sekä kirja-aineistoon että ajankohdan yhteiskunnallisiin muutoksiin, jotka vaikuttivat puutarhaviljelyyn ja sen kehitykseen. Kirjojen pääsisältönä on viljelymenetelmien ja erilaisten puutarhakasvien kasvatuksen opettaminen sekä kasvisten säilytysmenetelmien ja käyttömahdollisuuksien esittely. Käytännön oppien ohella ne sisältävät kuitenkin runsaasti myös kansalaiskasvatukseksi tulkitsemaani ainesta. Tutkimuksen kohteena on tarkastelemieni kirjojen sisältämä puutarhanhoitoa, kotipuutarhoja ja yleisemmin puutarhaviljelystä koskeva puhunta, jota tarkastelen kehittyvän puutarhakulttuurin kontekstissa. Näen puhunnan osaltaan kulttuuria muokkaavana tekijänä, mutta myös kulttuurin muutoksen heijastajana. Artikkelissa tutkin, miten kirjoissa perusteltiin puutarhaviljelyn tarpeellisuutta, millaisia arvoja kansan haluttiin omaksuvan viljelyn tuottaman aineellisen hyödyn ohella ja millainen oli se "hyvän ihmisen" malli, jota puutarhavalistuksella tavoiteltiin. Artikkeli myös valaisee tutkimusajankohdan puutarhakirjallisuuden kenttää ja tällä kentällä ilmeneviä erilaisia diskursseja.

\footnotetext{
$7 \quad$ Riksarkivet. Vanhimmissa tieto- ja opaskirjoissa ei välttämättä anneta tietoa alkuperäisteoksesta tai suomentajasta. Olen etsinyt taustatietoja kirjallisuudesta sekä Internet-lähteistä, esimerkiksi tekemällä hakuja Kansalliskirjaston digitoiduista lehtiaineistoista.

8

Kansa-käsitteestä ks. Mikkola 2009, 37; Stark 2006, 10.
} 


\section{Puutarhaoppia kansalle}

Tarkastelujakson aikana maatalouden painopiste siirtyi peltoviljelystä karjatalouteen, väestörakenne muuttui, yhteiskunnallinen liikehdintä oli voimakasta ja modernisaatio mullisti monin tavoin ihmisten arkea ja ajattelua. Suomi muuttui autonomisesta suuriruhtinaskunnasta itsenäiseksi valtioksi, jonka alkutaivalta leimasi yhteiskunnan poliittinen jakautuminen. Kansallisvaltion kehittyminen oli 1800-luvulla alkanut fennomaanisen sivistyneistön ohjailema prosessi. Siihen tarvittiin mukaan kaikkia yhteiskunnan kerroksia, mutta etenkin ihanteellistettua talonpoikaistoa, jonka nähtiin kansakunnan ytimenä. Kansallisen identiteetin rakentumisen ja kansallisen hengen syntymisen edellytyksenä oli yleisen sivistystason nostaminen, mikä tapahtui etenkin kansanopetuksen ja kansanvalistustyön avulla. Niiden tavoitteena oli kasvattaa oman paikkansa yhteiskunnassa täyttäviä, isänmaallisia kansalaisia. Merkittävässä roolissa valistustyössä olivat myös ajan monet kansanliikkeet. Liikkeillä ja poliittisilla järjestöillä oli erilaisia painopistealueita ja tavoitteita, mutta näkemys väestön suuren enemmistön, "kansan", sivistämisen tarpeellisuudesta oli yhteinen. (Vihola 1991; Koski 2011; Alapuro ym. 1987; Helsti ym. 2006; Päivärinne 2010.)

Yhtenäisen kansakunnan luominen edellytti maan taloudellisen tilanteen parantamista ja omavaraisuuden lisäämistä. Sen yhtenä edellytyksenä oli maanviljelyn tehostaminen, mutta esimerkiksi Kansanvalistusseura, Suomen Talousseura, maanviljelysseurat sekä Marttajärjestö halusivat edistää myös puutarhaviljelyä. Oppia kylille ja koteihin jakoivat erityisesti eri yhdistysten neuvojat, jotka opastivat kasvimaiden perustamista ja hoitoa käytännössä. He myös välittivät siemeniä ja taimia, joita ei ollut syrjäseuduilla juurikaan tarjolla. Tietoa levitettiin myös esimerkiksi maatalousalan koulujen, kansanopistojen ja kansakoulujen sekä maatalouskerhotoiminnan välityksellä. (Niemelä 1996; Niemelä 2008; Simonen 1961; Ollila 1993; Simonen 1953.) Lisäksi kansakunnan yhtenäisyyttä pyrittiin lujittamaan neuvontajärjestöjen kautta kanavoidulla rajaseututyöllä, jonka tarkoituksena oli kohottaa rajaseutujen elinoloja ja taloudellista tilannetta muun maan tasolle (Ollila 1993, 255-258; Niemelä 1996, 247-249).

Yksi väline, jolla sivistyneistö pyrki muokkaamaan kansaa toivotunlaiseksi, olivat painotuotteet. "Kansantajuista kirjallisuutta", erilaisia opas- ja tietokirjoja julkaistiin 1800-luvun lopussa ja 1900-luvun alussa kaikilta elämänalueilta. (Ojanen 2014, 17, 38-60; Kivistö 2013.) Opaskirjallisuutta ovat tutkineet esimerkiksi sosiologi Aino Sinnemäki (1991), historioitsijat Arja-Liisa Räisänen (1995) ja Tiina Männistö (2003) sekä mediatutkijat Anna-Maria MäkiKuutti ja Sinikka Torkkola (2014). Puutarhakirjoja ja -oppaita on kuitenkin tutkittu vasta vähän. Taidehistorioitsija Julia Donner (2015) on tarkastellut naisen ja puutarhan suhdetta käsittelevässä väitöstutkimuksessaan 1800- ja 1900-luvun taitteen suomenkielistä ja kansainvälistä puutarhakirjallisuutta, etenkin Jenny Elfvingin kirjoittamia puutarhakirjoja. Anni Leskinen (2007) on käyttänyt kansakoulun puutarhakirjoja yhtenä aineistoryhmänä kansakoulujen puutarha- ja maatalousopetusta käsittelevässä Suomen historian pro gradu -työssään. Lisäksi vanhoja kirjoja ja niiden sisältämiä tietoja on esitelty myös useissa uudemmissa puutarhakirjoissa (esim. Alanko ja Kahila 1994; Koskimies 2011; Savikko 2006).

Puutarhanhoito sijoittuu erityisellä tavalla luonnon ja kulttuurin välimaastoon; se on toimintaa, jossa ihminen muokkaa luontoa omien mieltymystensä mukaiseksi (Ross 2006; Donner $2015,36,181-182$ ). Luonto on perinteisesti tarjonnut inmiselle ravintoa, lääkkeitä ja monenlaisia raaka-aineita, mutta myös mielihyvää sekä merkkejä, joiden lukutaito on mahdollistanut ihmisen toimien oikea-aikaisuuden (Svanberg 2011). Suhde elantoa antavaan mutta 
myös pelottavana näyttäytyvään metsäluontoon on kuitenkin ollut kunnioittava, joten ihmisen asuttama alue on haluttu erottaa metsästä (Laaksonen ja Mettomäki 1994). Yläluokan aateliston ja sivistyneistön - moderniin luontokäsitykseen kuuluivat sen sijaan luonnon haltuunotto, kontrollointi ja hyväksikäyttö, mikä poikkesi kansan käsityksistä (Donner 2015, 36, 61-64). Pienten kotipuutarhojen muodostuminen ja erilaisten koriste- ja hyötykasvien vähittäinen levittäytyminen rahvaan pihoille on osoitus kulttuurin muutoksesta, jossa aiemmin lähes yksinomaan yläluokalle kuuluneista, sosiaalisen erottautumisen välineenä toimineista puutarhakasveista tuli vähitellen osa kaikkien kansankerrosten arkista elämää. Se edellytti rahvaalta arvojen muutosta ja uusien tapojen omaksumista, sillä puutarhaviljelyä pidettiin pitkään hyödyttömänä yläluokan huvina ja kasviksia lähinnä eläinten ruokana (esim. Parvela 1930, 164; Mikkola 2009, 246; Salonen ja Kurimo 1915, 9). Puutarhaviljelyn edistämiseksi tuli kansalle jakaa tietoa puutarhakasveista ja viljelytekniikoista, mutta myös kasvisten käytöstä ravintona. Pelkkä tieto ei kuitenkaan automaattisesti saa ihmisiä toimimaan, joten kansaa myös houkuteltiin ja taivuteltiin puutarhaviljelyn aloittamiseen eri keinoin. Donner (2015, esim. 74-76, 82-98) käsittelee tutkimuksessaan puutarhavalistusta sivistyneistön pyrkimysten näkökulmasta, itse kohdistan tässä artikkelissa huomion valistuksen sisältöön.

\section{Tutkimusaineistona puutarhakirjat}

Maassamme ilmestynyt puutarhanhoitoa käsittelevä kirjallisuus oli ennen Kaswutarha-kirjaa latinan- tai ruotsinkielistä; suomeksi oli julkaistu ainoastaan Turun Akatemian professori Pietari Adrian Gaddin 15-sivuinen vihkonen Lyhykäinen Ja Yxikertainen Neuwo Kuinga Krydimaan Yrttein Kaswannot, Suomen Maasa, Taittaan saatetta tuleundumaan (1768) sekä erilaisia lehtikirjoituksia (Saelan 1916). Toisen suuren puutarhaviljelyn edistäjän, professori (myöh. arkkiatri) Gabriel Bonsdorffin, vuonna 1804 julkaisema Sammandrag af Underrättelser, om sättet att anlägga en Köks-Trädgård För Husbehof oli varhainen ruotsinkielinen vähävaraiselle väestönosalle suunnattu puutarhaopas. Se oli 32-sivuinen vihkonen, jota jaettiin Bonsdorffin siemenkaupasta siementen ostajille ilmaiseksi. (Bonsdorff 2010, 14, 27, 87.) Ruotsissa julkaistua kirjallisuutta, jota sivistyneistö käytti, oli Suomessa hyvin saatavana ainakin suurimmilla paikkakunnilla (Hakapää 2008, 143-166).

Puutarha-alan ammattioppi ja kirjallisuus haettiin 1800-luvun lopussa ja 1900-luvun alussa ulkomailta, etenkin Ruotsista, Tanskasta ja Saksasta. 1850-luvulla ei suomen kielellä saanut painattaa muuta kuin uskontoa tai talousasioita käsittelevää kirjallisuutta sensuuriasetuksen vuoksi. 1860-luvulta alkaen erilaisia kansaa valistavia opaskirjoja ilmestyi runsaasti, ja myös suomenkielisten puutarhakirjojen määrä kasvoi nopeasti. (Kivistö 2013.) Kokosin tutkimusta varten bibliografian vuosina 1860-1950 ilmestyneistä suomenkielisistä puutarhakirjoista. ${ }^{9}$ Työvälineenäni olivat erilaiset hakuohjelmat, joista tärkein oli Suomen kansallisbibliografia Fennica. Bibliografian avulla sain selville, millaista puutarhakirjallisuutta eri aikoina julkaistiin, ketkä olivat tuotteliaimpia puutarhakirjojen kirjoittajia, mistä teoksista oli otettu pääasiassa teosten nimien ja kirjastoluokitusten avulla, mutta myös laajempia bibliografioita hyödyntäen. Yhtenä rajausperusteena on ollut sisällön painottuminen puutarhakasveihin ja niiden viljelyyn, joten esimerkiksi pelkästään huonekasveja tai peltoviljelykasveja käsittelevät teokset, kasvihuoneen tai kellarin rakennusoppaat ja ainoastaan sadon käsittelyä ja säilyttämistä käsittelevät kirjat on jätetty bibliografian ulkopuolelle, samoin kertomuksen muotoon puettu puutarhavalistus. Lisäksi määrään vaikuttaa se, millä perusteella teos luokitellaan kirjaksi, koska tarkasteluajanjakson aikana julkaistiin myös suuri määrä erilaisia opasvihkosia. Sivumäärärajana olen käyttänyt Unescon kirjan määritelmän (ks. Tieteen termipankki) mukaista 49:ä sivua, mutta koska varhaiset kirjat olivat pääsääntöisesti pienempiä, olen ottanut mukaan myös 1800 -luvulla julkaistut yli 40-sivuiset teokset. Julia Donner $(2015,89-98)$ on sivunnut tutkimuksessaan myös opasvihkosia, kaunokirjallista puutarhavalistusta ja puutarhojen mallipiirustuksia. 
useita painoksia sekä mitkä tahot kustansivat puutarhakirjoja. Etsin myös tietoja kirjoittajista ja kääntäjistä sekä heidän muusta toiminnastaan kirjallisuuslähteiden ${ }^{10}$ ja Kansalliskirjaston digitaalisten aineistojen avulla.

Aineistonvalintaprosessin aikana olen hankkinut käyttööni noin 70 bibliografiaan kuuluvaa kirjaa, joista olen valinnut tutkimusaineistoksi 40 vuosien 1860-1938 aikana julkaistua teosta. Olen kartuttanut tutkimusaineistoa useassa vaiheessa. Sen perustana on käytössäni ollut laaja puutarhakirjakokoelma, josta valikoin aluksi tarkasteltavaksi eniten puutarhaviljelyn perusteluja sisältäviä teoksia. Kirjamateriaaliin tutustumisen myötä aloin kiinnittää huomiota kirjoissa esiintyviin erilaisiin puhetapoihin ja hankkia käyttööni teoksia myös kokoelman ulkopuolelta. Tutkimuksen alkuvaiheessa tarkastelin yhdessä Taija Kaarlenkasken kanssa vanhoja puutarhan- ja karjanhoidon opaskirjoja pohtien niiden tuottamaa kuvaa "kansasta" ja sukupuolesta (Kaarlenkaski ja Piirainen 2014). Aineistonani oli tuolloin kymmenen nimensä tai esipuheensa perusteella suomenkieliselle aikuisväestölle, "kansalle", suunnattua hyötykasvien viljelyyn opastavaa kirjaa 1860-1920-luvuilta. Tämän artikkelin aineisto on laajempi sekä ajallisesti, sisällöllisesti että kirjojen kohderyhmän puolesta. Hyötykasvikirjojen lisäksi siihen kuuluu myös pelkästään koristekasveja käsitteleviä kirjoja sekä yleisemmin puutarha-alaan tai puutarhan suunnitteluun liittyviä teoksia. Joukossa on kotipuutarhaoppaita, ammattiviljelyyn tai alan opetukseen seminaareissa ja muissa oppilaitoksissa suunnattuja kirjoja sekä kansakoulun oppikirjoja, mutta ei aakkosellisia hakuteoksia.

Aineiston valintaa on ohjannut tavoite muodostaa tutkimusajankohtana julkaistuista suomenkielisistä puutarhakirjoista monipuolinen otos. Kirjoja on useilta eri kustantajilta ja myös erilaisista valistuskirjasarjoista. Olen valinnut tutkimusaineistoon teoksia ajankohdan merkittävimmiltä ja tuotteliaimmilta suomalaisilta kirjoittajilta, jotka olivat myös maamme puutarha-alan kehitykseen vaikuttaneita toimijoita. Monet kirjoista ovat ajanjakson keskeisiä teoksia, joista otettiin useita painoksia. ${ }^{11}$ Valinnassa on huomioitu myös kirjojen leviäminen eri puolille maata kirjastojen, kansakoululaitoksen ja järjestöjen välityksellä sekä käyttö oppikirjoina, mikäli siitä on ollut tietoa. Katson siis tutkimusaineiston edustavan riittävän kattavasti kirjojen sisältämää puutarhapuhetta, joka joko suoraan tai välillisesti oppilaitosten kautta tavoitti suomalaiset 1800-luvun lopussa ja 1900-luvun alkuvuosikymmeninä.

Seuraavaksi esittelen tutkimusaineiston ja teosten kirjoittajat. Tarkastelen ensin vanhimpia kirjoja, joista osa on käännetty ulkomaalaisista teoksista, ja sen jälkeen myöhäisempiä suomalaisten kirjoittajien teoksia.

\section{Puutarhakirjat ja niiden kirjoittajat}

Ulkomaalaisia puutarhakirjoja käännettiin suomeksi lähes suoraan muiden kuin puutarha-ammattilaisten toimesta. ${ }^{12}$ Suomen ilmasto ja siten myös viljelyolosuhteet kuitenkin vaihtelivat huomattavasti eri puolilla maata ja poikkesivat monilta osin esimerkiksi Ruotsin

\footnotetext{
$10 \quad$ Esim. Alanko ja Kahila 1994, 29-53; Simonen 1961; Donner 2015; Kuka kukin on (Aikalaiskirja) 1954.

11 Esim. Lindgren 1903 (5 painosta, viimeinen 1920), Kalervo 1923 [1922] (5 painosta, viimeinen 1927), Pöyhönen ja Pöyhönen 1927 (6 painosta, viimeinen 1950), Salonen ja Jaatinen 1933 (10 painosta, viimeinen 1961) ja Lehtonen 1934 (8 painosta, viimeinen 1953). Lisäksi kuudestatoista kirjasta on otettu 2-4 painosta.

12 Enerothin (1860) teoksen suomentaja oli kartanonomistaja, kirjailija ja protokollasihteeri Fredrik August von Platen, Holmin (1875) kirjan käänsi "tieteellinen ja paranteellinen tohtori" Samuel Roos, joka suomensi suuren määrän eri alojen teoksia (Kivistö 2013, 533).
} 
oloista (ks. Kersalo ja Pirinen 2009; Svensk Trädgård; Lagerström 2018). Lisäksi puutarhaviljely oli Suomessa 1800-luvun lopulla vielä hyvin vähäistä etenkin sisämaassa ja esimerkiksi marjanviljely maan pohjoisosissa alkutekijöissään vielä 1920-luvulla (esim. Heikel 1919, 23; Parvela 1930, 189-191). Kirjoittajien maailma saattoi siten olla hyvin kaukana valistettavien todellisuudesta. Näin oli etenkin tukholmalaisen kauppapuutarhuri J. F. Holmin teoksessa Ruoka-kaswiston hoidanta (1875), mistä huomautettiin jo aikalaisarvostelussakin (Kivistö 2013, 533). Silti teosta myös kehuttiin kritiikittä (Satakunta no 44, 30.10.1875), vaikka kirjassa muun muassa esiteltiin lähes 40 suurimarjaista mansikkalajiketta sekä runkomaisiksi kasvatettujen puna- ja valkoherukoiden hyötämistä varhain keväällä pöydän koristeiksi (Holm $1875,84-86,93)$.

Ulkomaalaisten puutarhakirjojen sovittaminen Suomen oloihin lisäsi niiden käyttöarvoa huomattavasti. Norjalaisen F. C. Schübelerin teoksen Kasvitarha, sen hyöty ja arvo taloudessa (1884) "mukailemalla suomensi" Sortavalan seminaarin lehtori, Laatokan Karjalan puutarhanhoidon isäksikin kutsuttu Arvid Th. Genetz (Simonen 1961, 192). Kasvien viljelyohjeet ovat Genetzin mukaan soveltuneet lähes sellaisenaan, mutta kirjan sisältämiä ruokaohjeita hän kertoo muokanneensa karjalaiseen ruokakulttuuriin sopivaksi. (Schübeler 1884, VII, Suomentajan esipuhe.) Tutkimusaineiston kaksi muuta ulkomaalaistaustaista teosta ovat ruotsalaisia ja suomalaisten puutarha-alan ammattilaisten maamme oloihin sovittamia. Erik Lindgrenin Kasvitarhakirjan (1903) sovittaminen ja laajentaminen oli erityisen huolellista. Sen teki ruotsalaislähtöinen Mustialan puutarhuri Klas Stening käyttäen apunaan huomattavaa joukkoa suomalaisia alan ammattilaisia. Rudolf Abelinin Pikkupuutarhan (1908, 1912 ja 1917) sovittivat Suomen oloihin B. W. Heikel sekä Ossian Lundén. Molemmat vaikuttivat monin tavoin alan kehitykseen Suomessa ja kirjoittivat useita omia teoksia, joita on mukana myös tässä tarkastelussa.

Jotkut aineiston käännöskirjoista ovat Suomessa ruotsiksi kirjoitettujen teosten suomennoksia. Vanhin kotimaista alkuperää oleva puutarhakirja on C. G. Söderbergin Hedelmäpuiden ja Marjapensasten kaswattamisesta (1862), joka kuului Kaswutarha-kirjan ohella kirjastojen kokoelmiin. ${ }^{13}$ Söderberg oli yksi maan hedelmänviljelyn edelläkävijöistä, joka toimi Länsi-Suomessa, erityisesti Satakunnan alueella. Söderberg palkittiin kirjastaan Suomen Talousseuran kirjailijapalkinnolla vuonna 1867 (Puutarha 1.2.1908, 16). Söderbergin ohella ruotsiksi kirjoittivat Ossian Lundén sekä tunnettu hedelmänviljelyn uranuurtaja, Enerothin opissa ollut pomologi Alexandra Smirnoff. Hän tutki hedelmänviljelyä sekä Suomessa, Ruotsissa että Venäjällä ja edisti sitä neuvontatyöllään ja kirjoituksillaan. Smirnoffilta on mukana kolme teosta, joista kaksi kuuluu valistuskirjasarjoihin: Punhedelmien wiljelemisesta Suomessa (1893) sekä Käsikirja yksinkertaisessa puutarhanhoidossa (1901 ja 1904).

Kansakoulun puutarhaopetuksen tarpeisiin julkaistiin monia kirjoja, joista useimpien toivottiin levittävän oppia myös koteihin. Genetz oli kääntänyt Schübelerin (1884) teoksen seminaarien kansakoulunopettajien puutarhaopetuksen oppikirjaksi, mutta seuraavat kansakoulun puutarhaopetusta varten kirjoitetut kirjat olivat kotimaista alkuperää. Genetzin oma Kansan ja kansakoulun kasvitarhakirja (1894) on koululaisille ja tavalliselle kansalle suunnattu yleisteos, jonka tekstisisällössä ei kansakoulua kuitenkaan mainita. Pedagogi ja kansanrunouden tutkija Oskar Relanderin Puutarhakirja kansakouluja varten (1905) on tarkoitettu kansakoulun, erityisesti jatkokurssien oppikirjaksi, mutta myös kotipuutarhanhoidon 
ohjekirjaksi. Lisäksi kirjoittaja arvelee sen voivan toimia puutarhaopin oppikirjana myös alemmissa maanviljelyskouluissa sekä kansanopistoissa. (Relander 1905, esipuhe.)

Puutarhuri ja kansakoulunopettaja Matti Hyvösen Koulupuutarha: Käsikirja koulupuutarhan perustamista ja hoitoa varten (1913) oli suunnattu kansakoulunopettajien ohella seminaarien puutarhureille sekä puutarhaneuvojille, joten se oli tietomäärältään laajempi kuin oppilaiden kirjat. Hyvösen Nuorten puutarhakirja (1914) oli puolestaan tarkoitettu Koulupuutarhan rinnalle oppilaiden käyttöön. Tutkimusaineistoon kuuluu myös kaksi muuta kansakoulun oppikirjaa: kansakoulujen puutarhaopetuksen neuvoja Kalle Kalervon Nuori Tarhuri (1. painos 1922) sekä maataloushallituksen puutarhanhoidon tarkastaja Gustaf Ignatiuksen Lyhyt puutarhanhoidon oppikirja (1929). Lisäksi tutkimuksessa on mukana Suomen Koulukasvitarhayhdistyksessä toimineen opettaja H. V. Luukon Sydänjuuret maahan! Koulukasvitarhat kansantaloudellisina ja pedagoogisina kasvatusvälineinä (1918), joka jaettiin kaikkiin maan suomenkielisiin kansakouluihin. Kirja ei sisällä viljelyohjeita, vaan esittelee ja perustelee koulupuutarha-aatetta, sen tehtäviä ja kasvatuksellista merkitystä.

Myös kotipuutarhojen viljelyä varten julkaistiin lukuisia teoksia, joista osaa käytettiin myös oppikirjoina etenkin kotitalous- ja maanviljelysalan kouluissa ja kursseilla. Tutkimusaineistoon kuuluvat Ossian Lundénin Kotipuutarhan Työkalenteri (1912), Kaarlo Vanamon Keittiökasvien viljelys (1912) sekä Matti Hyvösen Koulupuutarhan pohjalta vuonna 1914 tekemä Kotipuutarhuri. Kalle Kalervon Kaikille kasviksia ja hedelmiä (1912) on kokoelma aiemmin julkaistuja kirjoituksia, Käytännöllinen puutarhanhoito (1925 [1915]) yksityistarpeeseen ja oppikirjaksi suunnattu teos ja Käytännöllisiä ohjeita puutarhanhoitajille (1931) siemenliikkeen asiakkailleen jakama opaskirja.

Frans Salonen oli erityisen tuottelias puutarhakirjailija, joka suuntasi kirjansa etenkin koti- ja harrastelijapuutarhureille. Salosen tuotantoa edustaa tässä tarkastelussa kaksi omaa teosta, Keittiökasvien ja marjain viljelys (1925) ja Aikainen vihannesviljelys (1935). Lisäksi mukana on Kalle Jaatisen kanssa kirjoitettu Kodin puutarha (1933) sekä Salosen ja Anna Kurimon yhteisteos Kotien puutarhakirja ja lyhyt säilöönpano-opas (1915). Nora Pöyhönen oli edelläkävijä puutarhaviljelyn kokeilijana ja edistäjänä erityisesti Pohjois-Suomessa, mutta myös naisten puutarhakoulutuksessa. Hänen perustamansa Haapaveden kasvitarha- ja keittokoulu levitti oppilaidensa välityksellä puutarhaviljelyn ja kasvisten käytön taitoa koko maahan. Pöyhösen yhdessä tyttärensä Maijun kanssa kirjoittama Kodin kasvitarha (1927) oli suosittu puutarhan yleisteos. (Ruoff 2006.) Sellainen oli myös Lepaan hedelmänviljelyn opettaja Väinö Lehtosen Puutarhakirja maatalouskouluja ja itseopiskelua varten (1934), josta otettiin kymmenen painosta.

Suurin osa edellä kuvatuista teoksista on eri tavoin painottuneita yleisteoksia, joissa käsitellään puutarhan perustamista ja hoitoa sekä esitellään vihannesten, marjojen ja hedelmien sekä usein myös koristekasvien viljelyä. Myös johonkin puutarhaviljelyn osa-alueeseen keskittyviä kirjoja julkaistiin paljon etenkin tarkastelujakson loppupuolella. Niihin lukeutuvat Ossian Lundénin laaja ja arvostettu Keittiökasvikirja (1. painos 1913) sekä lannoitealan kehittäjän ja Kekkilän puutarhan perustajan Mikko Jortikan Koti- ja huvilapuutarhat: Perustaminen, istutus, lannoitus ja maanjärjestelyt kemiallisia ja kasvifysiologisia seikkoja silmälläpitäen (1929). Hedelmien ja marjojen viljelyä käsitteleviä teoksia on aineistossa useita, koska erityisesti omenanviljelyyn asetettiin suuria toiveita 1800-luvulla ja 1900-luvun alussa. Lisäksi hedelmien ja marjojen viljelyn ajateltiin olevan kansalle helpommin omaksuttavaa kuin 
vihannesten, joiden valmistus ja käyttö tuli varta vasten opetella. 1900-luvun marjan- ja hedelmänviljelykirjoista on tutkimusaineistoon otettu B. W. Heikelin Hedelmän- ja marjanviljelys avomaalla (1919 [1913]) sekä Olavi Collanin Hedelmän- ja marjanviljelyksen käsikirja (1929) ja Kodin hedelmätarha (1933). Sekä Heikell että Collan olivat Lepaan puutarhaopiston opettajia, mutta myös valtionpomologeja.

Tutkimusaineistoon kuuluu myös pelkästään koristekasveihin keskittyviä kirjoja, joita julkaistiin 1910-luvulta alkaen. Kukkien viljelyä ja niiden käyttöä opastavia kotimaisia teoksia ovat Alexandra Smirnoffin Kukkaistarhan hoito (1910), Jenny Elfvingin Kukkaviljelys avomaalla (1921) sekä puutarhuri Richard Karlssonin ${ }^{14}$ Kodin kukkastarha (1924). Erityisesti naisten puutarhaopetusta edistäneen Elfvingin kirjallisessa tuotannossa painottui taiteellisten näkökohtien huomioiminen kotipuutarhojen suunnittelussa (Donner 2015). Sekä puuvartisia kasveja että perennoja käsittelee Luonnonkasvit kotien kaunistuksena (1917), jonka kirjoittaja on Suomen kanavien ylipuutarhuri Matti Parikka. Pelkästään pensaisiin keskittyy puolestaan puutarhasuunnittelijan ja koristekasviviljelyn edistäjän Bengt Schalinin Koristepensaista kauneimmat (1938). Esteettistä valistusta ja kotipuutarhojen suunnittelua edustavat Annikki Reijosen ainoa puutarha-alan teos Puutarhakauneus (1927) sekä taideteollisuuden alalla monipuolisesti toimineen Edvard Eleniuksen Kotiemme kauneus (1915), joka neuvoo myös asuinrakennusten ja sisustuksen suunnittelua. Ossian Lundénin Ryhmäpuutarhoja (1918) käsittelee laajasti siirtolapuutarhatoiminnan yhteiskunnallista merkitystä sekä toteuttamista käytännössä.

Puutarhakirjoja julkaistiin siis erilaisiin tarpeisiin: orastavaa ammattiviljelyä, kansakoulun puutarhaopetusta ja kotitarveviljelyä varten. Sekä esipuheissa että aikalaisarvosteluissa todetaan usein tietynlaisen kirjan puute, jonka vuoksi kirjoittaja on tarttunut toimeen. Kirjoja kirjoitettiin myös esimerkiksi eri järjestöjen tai muiden tahojen tilauksesta tai rohkaisemina, ja monet esipuheet kertovat taipumisesta näihin pyyntöihin. Usein kirjojen toivottiin myös palvelevan eri käyttäjäryhmiä, esimerkiksi kotipuutarhakirjojen toivottiin soveltuvan kansanopistoissa, maanviljelys- ja talouskouluissa sekä puutarhakursseilla käytettäväksi. Koska puutarhaviljely oli suurelle osalle kansaa vierasta, joutuivat tällaisten teosten kirjoittajat pohtimaan esitystapaansa. Vaikka myös pidemmälle ehtineille tuli tarjota tietoa, tuli tekstin olla sellaista, että sen ymmärtäminen oli mahdollista myös aloittelijoille ja itseopiskelijoille. Kansakoululaisille suunnatut kirjat puolestaan olivat yksinkertaisia ja helppolukuisia, koska niiden avulla oli tarkoitus levittää tietoa myös niihin maaseudun koteihin, joissa puutarhaviljelystä ei harjoitettu.

Lehtien ja kirjojen merkitys puutarhatiedon levittämisessä on ollut suuri, koska puutarha-alan ammatilliset järjestöt eivät voineet juuri antaa käytännöllistä puutarhaneuvontaa ja se jäi sellaisten järjestöjen huoleksi, joilla oli myös monenlaisia muita toiminnan muotoja (Simonen 1961, 427-428). Kirjojen määrän lisääntyessä niitä kirjoitettiin selvemmin erilaisia yleisöjä varten. Suomen ensimmäisen korkeampaa koulutusta tarjonneen puutarhaoppilaitoksen, Lepaan puutarhaopiston, perustaminen näkyy myös alan ammattikirjallisuuden ja erikoisteosten lisääntymisenä 1910-luvun lopulta alkaen. ${ }^{15}$ Menekki ei silti ollut välttämättä suurta edes ammattiväen keskuudessa (Puutarha no 1, 1.1.1928, 4). 1930-luvun lopulta lähtien julkaistiin runsaasti erilaisia opasvihkosia, joita kustansivat muun muassa eri järjestöt.

\footnotetext{
14 Myöhemmin Riku Kasterinne.

15 Lepaan puutarhaopisto perustettiin vuonna 1910, ja sen ensimmäinen vuosikurssi aloitti kaksivuotisen opiskelun vuonna 1912 (Haapanen ym. 1935).
} 
Suurin osa puutarhakirjojen tekijöistä kirjoitti myös puutarhalehtiin, joita ilmestyi tarkastelujaksolla useita. Niistä etenkin Suomen puutarhaviljelijäin liiton julkaisema Puutarha (1898 alkaen) oli tärkeä ajankohtaisen tiedon välityskanava ja keskustelufoorumi.

Kirjoittajien taustat ja koulutustasot olivat moninaiset. Kansakoulun kasvitarhaopetusta käsitteleviä kirjoja kirjoittivat ainoastaan miehet, ${ }^{16}$ mutta puutarha-alan uranuurtajien joukossa oli myös paljon naisia. Lähes kaikki kirjoittajat toimivat hyvin monella saralla: he tekivät opetus- ja neuvontatyötä, toimittivat lehtiä, toimivat erilaissa järjestöissä sekä perustivat ja johtivat oppilaitoksia ja yrityksiä. Hyvin monet olivat hankkineet koulutuksensa Suomen ulkopuolella. He myös tekivät opintomatkoja ulkomaille ja toivat sieltä vaikutteita kotimaahan. (Ks. esim. Alanko 2005 ja 2007; Ruoff 2001b, 2006 ja 2007; Simonen 1961.) Läheinen kosketus käytännön puutarhatyöhön olikin tarpeen, sillä 1920-luvulle saakka keskusteltiin siitä, missä määrin kasvitarha- ja hedelmänviljelys olisi ylipäätään mahdollista maassamme. Ilmastollisten erojen olemassaolo tiedostettiin, mutta niiden asettamista rajoituksista ei ollut tietoa. Kirjat ovat periaatteessa yksisuuntainen viestintäväline, mutta osa kirjoittajista toivoi saavansa kuulla kokemuksia kasvien menestymisestä eri alueilla. Kasvien menestyminen oli aaltoliikettä; hyvien, uskoa nostattavien vuosien jälkeen saattoi tulla pakkastalvia tai kasvitauteja, jotka tuhosivat tehdyn työn. Alan kehitys vaikutti uusintapainoksiin, joita muokattiin ja täydennettiin tarpeen mukaan. Muutoksia tehtiin erityisesti lannoituksen ja kasvinsuojelun osalta. Lisäksi kirjoittajat joutuivat ottamaan kantaa puutarha-alan suomenkieliseen sanastoon, joka oli vasta kehittymässä. (Esim. Lindgren 1918, V-VIII.)

\section{Tutkimusmenetelmät}

Aineistonmuodostusprosessin aikana luin valittuja kirjoja kiinnittäen huomiota erityisesti kohtiin, jotka vastaavat kysymykseen "Miksi puutarhaviljelyä tulisi harjoittaa?" ja kirjasin ne ylös nykysuomeksi. Etenkin kirjojen esipuheet ja alkulauseet sisältävät perusteluja puutarhaviljelyn harjoittamiselle. ${ }^{17}$ Kansalle suunnatut pienet, hinnaltaan edulliset opaskirjaset keskittyivät käytännön ohjeiden antamiseen ja sisälsivät perusteluja usein vain vähän, joskus ei lainkaan. Olen poiminut aineistosta myös maininnat kansasta ja kasvatuksesta sekä esimerkiksi ajankohdan puutarhaviljelyn tilaa käsittelevät toteamukset, kuten havainnot ja mielipiteet puutarhaviljelyn edistymisestä maassamme. Kukin ajatuksellinen kokonaisuus, eli väite, mielipide tai havainto muodostaa oman analyysiyksikkönsä, johon on liitetty viitetieto.

Seuraavassa vaiheessa ryhmittelin teoksista poimitut analyysiyksiköt tutkimuskysymysten mukaisiin teemoihin ja nämä edelleen pienemmiksi, aineiston mukaan hahmottuviksi ryhmiksi. Kysymykseen "Miksi puutarhaviljelyä tulisi harjoittaa?" vastaavista väitteistä on erotettu esimerkiksi taloudellisia ja terveydellisiä perusteluja. Taloudelliset perustelut voi jakaa yksityisille talouksille koituviin ja kansantaloudellisiin hyötyihin, terveydelliset argumentit puolestaan ravinnon määrään ja laatuun liittyviin sekä puutarhanhoidon tarjoamaan liikuntaan ja ulkoilmaan kytkeytyviin perusteisiin. Olen ryhmitellyt teemat edelleen aineellisiin ja aineettomiin etuihin ja lukenut niitä rinnakkain kansaa koskevan puhunnan ja muiden teemojen kanssa.

16 Elli Tavastähden Koululaisen kasvitarhaopas (1914) on 19-sivuinen vihko.

17 Vastaavalaista aineistoa ovat tutkimuksessaan käyttäneet Anna-Maria Mäki-Kuutti ja Sinikka Torkkola (2014). 
Tematisoinnin ja ryhmittelyn tuloksena tutkimusaineistoista on lajittunut erilaisia samaa aihepiiriä käsitteleviä ja samantapaisia väitteitä. Vaikka tässä tarkasteltavat teemat ovat myös määrällisesti selkeimmin erottuvia, on tutkimusaineiston tarkastelu kvalitatiivista. Tarkastelen analyysissa teemakokonaisuuksia kiinnittäen huomiota ajalliseen muutokseen eli siihen, mistä kulloinkin puhuttiin. Identifioiduista yksiköistä ilmenee, millaisia väitteitä kussakin kirjassa esitettiin ja miten niitä perusteltiin. Lisäksi kiinnitän huomiota siihen, mistä vaiettiin, sillä eri kirjoissa painotetaan erilaisia asioita, eikä monissa teoksissa ole lainkaan vaikuttamaan pyrkivää puhuntaa. Hyödynnän tutkimusaineiston tarkastelussa lähdekirjallisuuden lisäksi myös puutarha-alan ammatillista tietämystäni (ks. Piirainen 2016, 181-184). Seuraavaksi tarkastelen aineistosta hahmottamiani keskeisiä teemakokonaisuuksia ja teen niistä yhteenvetoa. Koska operoin pilkotulla aineistolla, esitän tekstissä vain yksittäisiä aineistositaatteja.

\section{Lähtökohtana hyöty}

Puutarhaviljelyn edistämisen tärkeimpänä motiivina erottuu viljelyn tuottama aineellinen hyöty. Suomessa koettiin monia katovuosia 1700-luvun lopussa ja 1800-luvulla (Voutilainen 2016, 94-95). Erityisen pahoja olivat 1860-luvun kadot. 1860-luvun nälänhädät syntyivät perättäisten katovuosien ja yhteiskunnallisten tekijöiden yhteisvaikutuksesta ja ne koskettivat lähes koko maata. 1800-luvun Suomi oli erittäin köyhä, mutta myös hyvin epätasa-arvoinen maa. Erot sekä alueellisesti että yhteiskuntaluokkien välillä olivat suuret ja toimeentulomahdollisuudet vaihtelivat maan eri osien välillä. (Häkkinen ym. 1991; Jussila ja Rantanen 2018; Turpeinen 1986; Voutilainen 2016.) Kainuussa ja Koillismaalla oli useita nälänhätiä vielä 1900-luvun taitteessa, ja 1910-luvun lopulla nähtiin nälkää koko maassa (Turpeinen 1985, 202-203; Laitinen 2012, 176-180). Vielä 1930-luvun pulan aikaan maaseudun maata omistamattomien ja pienviljelijöiden sekä kaupunkien työläisten ravinto oli hyvin niukkaa ja yksipuolista (Virkkunen 2010, 74-91; Peltola 2008, 69-88).

Kansan ravitsemus perustui erityisesti maan syrjäseuduilla vielä 1900-luvun alussa lähes täysin viljaan ja perunaan, jotka ovat arkoja hallalle. Ruisleivän osuus kansan ruokavaliossa oli keskeinen, joten ruissadon epäonnistuminen aiheutti nälänhätää katovuosina. Maan keskija pohjoisosissa käytettiin myös normaalivuosina jauhojen lisänä yleisesti korvikkeita, erityisesti pettua. (Vornanen 2018, 171-176; Voutilainen 2016, 89-91.) Monet vihannekset kuitenkin jatkavat kasvuaan hallayön jälkeenkin, joten opettamalla kansaa kasvattamaan erilaisia vihanneksia ravinnokseen oli mahdollista turvata huonojen vuosien ravinnonsaantia. Puutarhakirjoissa muistutettiin katovuoden mahdollisuudesta ja perusteltiin kasvitarhaviljelyn tarpeellisuutta nälänhädän ehkäisijänä 1930-luvulle saakka (Genetz 1894; Kalervo 1912; Salonen ja Kurimo 1915; Salonen 1925; Salonen ja Jaatinen 1933). Lisäksi se, että ihmisten voimavarat kuluivat jokapäiväisen leivän hankkimiseen, oli yksi kansan sivistämisen esteistä. Kasvitarhaviljelyn avulla voitaisiin edes osa kansan kurjuudesta ja puutteesta poistaa ja saada ihmisten ajatukset suuntautumaan tulevaisuuteen. (Schübeler 1884, VI.)

Ruoan määrän ohella esiin nostettiin sen laatu: kansan ruokavalio kaipasi kirjoittajien mielestä monipuolistamista, joten kasvitarhaviljely edistäisi kansan terveyttä ja fyysistä hyvinvointia terveellisemmän ja vaihtelevamman ravinnon myötä. Kasvisravinnon terveellisyyden perustelut muuttuivat ajan kuluessa. Vanhimmissa kirjoissa kasviksia suositeltiin etenkin estämään keripukkia ja edistämään ruoansulatusta. Erityisen tarpeellisia ne olivat istumatyöläisille; ruumiillisen työn tekijä ei niitä välttämättä edes tarvinnut (Holm [Roos] 1875, V). 
Palkokasvien tiedettiin jo varhain olevan erittäin ravitsevia, ja niitä suositeltiin erityisesti raskasta työtä tekevien ja harvoin lihaa syövien ravinnoksi (erit. Schübeler 1884, 67; Genetz 1894, 14; Smirnoff 1904, 63, 69). 1920- ja 1930-luvun teoksissa kasvisruokia mainostettiin maukkaiksi sekä terveyttä ja hyvinvointia edistäviksi, vaikka niiden suurin merkitys oli edelleen leipäviljan korvaamisessa. Kasvisten sisältämien ravintoaineiden ja vitamiinien olemassaolosta oltiin jo tietoisia, mutta eri vitamiineja ja niiden vaikutusmekanismeja ei tunnettu vielä tarkasti (Lundén 1921, 3-9). "Kun tiede lopullisesti kykenee ratkaisemaan vitamiinikysymyksen, uskomme, että puutarhatuotteet sen jälkeen tulevat saamaan entistään suuremman arvon ravintonamme ja terveytemme ylläpitäjänä" (Salonen 1925, 9). Kasvisravinnon hyötyjä tuodaan esiin erityisesti 1910-1930-luvuilla julkaistuissa kirjoissa, aikana, jolloin myös vegetarianismiaate alkoi yleistyä Suomessa (Piirainen 2013).

Myös itse puutarhatyö, ruumiillinen työskentely, todettiin terveyttä edistäväksi, vaikka perusteluja tälle esitettiinkin vain vähän. Erityisen hyödylliseksi puutarhassa työskentelyn ja oleskelun teki raikas ulkoilma. Ajan terveysvalistus todisti samaa: karaistuneeseen ruumiiseen eivät taudit helposti tartu ja valo ja raikas ilma ovat yksi terveyden edellytyksistä. Lisäksi työteliäs elämä ja säännöllinen elämäjärjestys nähtiin parhaaksi keinoksi välttää "sekä ruumiillista että henkistä ruttotautia". (Lehtonen 1995, 239-240.) Osa kirjoittajista myös korosti, että sisätilojen tuli olla valoisia eivätkä puut saaneet varjostaa itse asuinrakennuksia (esim. Abelin 1912, 12; Jortikka 1929, 38-39).

Puutarhaviljelyn puolesta esitettiin runsaasti taloudellisia perusteluita koko tarkastelujakson ajan. Puutarhaviljely oli kirjoittajien mukaan edullista ja siitä koituva hyöty miltei jokaisen saavutettavissa, koska alkuun pääsemiseksi ei tarvittu pääomaa, ainoastaan pieni pala maata ja omaa työtä. Maaseudulla pienenkin mökin asukkaalla oli mahdollisuus kasvattaa ainakin joitain kasveja ja ryhmäpuutarhapalsta tarjosi monelle kaupungissa asuvalle työläisperheelle saman mahdollisuuden. Puutarhan tuotteiden avulla kotitalouksien oli mahdollista saavuttaa hyötyä monin eri tavoin: kasvisten käyttö ravintona vähensi elintarvikkeiden ostotarvetta ja kasvisten syöttäminen eläimille säästi arvokkaita elintarvikkeita ihmisravinnoksi. Sopivien tuotteiden myynnillä saattoi puutarhaviljelystä saada etenkin kaupunkien läheisyydessä hyvän tuoton. Pienviljelysten määrä lisääntyi 1900-luvun alussa voimakkaasti, kun maattoman väestön määrää haluttiin pienentää asutustoiminnan avulla, mutta syntyneiden tilojen pieni koko edellytti tiloilta pinta-alaan nähden suurta tuottavuutta toimeentulon takaamiseksi (Niemelä 2008, 122-141). Pienviljelysten mahdollisuudet elannon tuottamiseen lisääntyivät puutarhaviljelyn avulla, koska hyvin hoidettu kasvitarha voi tuottaa pinta-alaan nähden huomattavasti paremmin kuin pelto. Se ei myöskään vienyt resursseja maataloudelta, koska maan lannoittamiseen saattoi käyttää aiemmin hyödyntämättömiä talousjätteitä ja fyysisesti kevyeen puutarhatyöhön kykenivät myös naiset, lapset ja vanhukset.

Puutarhaviljelylle esitettiin tutkimusaineistossa myös kansantaloudellisia perusteita. Taloudellinen toiminta ja hyvinvointi toimivat pohjana muulle kehitykselle, joten isänmaallisuus tarkoitti konkreettista työtä ja toimintaa isänmaan hyväksi (Ollila 1993, 33). Kirjoittajat toivat voimakkaasti esiin koko tarkastelujakson ajan, miten maahan tuotiin ulkomailta suuret määrät vihanneksia ja hedelmiä, joita olisi mahdollista kasvattaa kotimaassakin. Kirjoissa annettiin esimerkkejä ulkomaantuonnista ja esitettiin laskelmia, joiden mukaan maan taloutta voitaisiin ratkaisevasti parantaa viljelemällä kasviksia itse. Kasvisten viljely hyödyttäisi perheen taloutta, mutta olisi samalla isänmaallinen teko. Myös vihannesten ja juuresten 
siementen viljelyä neuvottiin paljon ja siihen kannustettiin voimakkaasti aina 1930-luvulle saakka. Tämän yksinkertaisen työn avulla jokainen saattoi ottaa osaa yleisen hyvinvoinnin lisäämiseen helposti oman talouden kohentamisen ohessa, sillä siementen kysyntä oli suurta. Lukijoita neuvottiin myös kasvattamaan omenapuita siemenistä ja annettiin ohjeita puiden jalontamiseen. ${ }^{18}$ Opettelemalla näitä töitä oli kenen tahansa mahdollista parantaa puutarhakasvien menestymismahdollisuuksia maamme olosuhteissa ja samalla lisätä kansakunnan omavaraisuutta. ${ }^{19}$

\section{lloa puutarhasta}

Puutarhaviljelylle esitettiin siis runsaasti rationaalisia perusteita, mutta sen kerrottiin tuottavan myös paljon mielihyvää. Puutarha tuotti kirjoittajien mukaan sellaista työn iloa, jota ei ollut muilla keinoilla mahdollista saada. Se oli tervettä ja raikasta, täysin toisenlaista kuin "varieté-huvitusten ja elävienkuvien teatterien synnyttämä" teennäinen ja pintapuolinen ilontunne, jota oli kaupungeissa tarjolla (Lundén 1918, 16-17). Puutarhan merkitys kodin kaunistajana ja kodikkuuden lisääjänä nousee voimakkaasti esiin koko aineistossa, vaikka koristekasveista puhuttiin enemmän vasta 1900 -luvun kirjoissa. Kauneuden synnyttäjiä olivat hyvin hoidettu kasvimaa sekä erityisesti 1800-luvun ja 1900-luvun alun kirjoissa, ennen vuosien 1915-1916 tuhoa, hedelmäpuut.

Hyötykasvit tarjosivat virikettä aisteille joka vaiheessa. Kasvisten, hedelmien ja marjojen todettiin olevan värikkäitä ja silmää miellyttäviä sekä kasvaessaan että ruoaksi valmistettuina. Lisäksi niiden kerrottiin tarjoavan monipuolisia makuelämyksiä. Höyryävät, tuoksuvat, tuoreet ja värikkäät kasvisruoat olivat siis aivan toista maata kuin kansan kuiva leipä ja liha. Kukat olivat kirjoittajien mukaan sallittavaa ylellisyyttä ja viatonta huvia: vaikka ne ovat sinänsä tarpeettomia, tuottavat ne kuitenkin inmisille paljon iloa ja poistavat ankeutta elämästä. Myös kukkien tuoksut mainitaan kirjoissa usein. Tuoksut olivat osa miellyttävää ympäristöä ja kukkien tuoksua pidettiin hyvin tärkeänä (Alanko ja Kahila 1994, 183). Puutarhanhoitoa harrastanut 1800-luvun lopun sivistyneistö oli myös harjaantunut havainnoimaan tuoksuja, ja niitä käytettiin esimerkiksi muistelun välineinä (Ollila 2000, 80-82). Kasveissa oli sata vuotta sitten enemmän tuoksuja kuin nykyään; kasvinjalostuksella on tavoiteltu aina vain suurempia, värikkäämpiä ja kerrotumpia kukkia, joiden saavuttamisen hintana on usein ollut tuoksun väheneminen. Hajumaailma on ollut tuolloin toisenlainen kuin nykyään, mutta miellyttävien tuoksujen arvostamista ja löyhkän karttamista on pidetty myös yhtenä sivistyksen merkkinä (ks. Salmi 2000).

Puutarhan haluttiin tuottavan iloa arjessa: kukkaistutukset neuvottiin sijoittamaan porraspieliin ja ikkunoiden alle, että niihin saattoi luoda silmäyksen kiireistenkin töiden lomassa. Kotien ympärille istutettujen kasvien kerrottiin lisäävän koko seudun viihtyisyyttä ja ilahduttavan ohikulkijoita, joten niiden vaikutus säteili myös ulospäin. Ympäristön kaunistaminen koristekasveilla oli mahdollista ja suotavaa kaikille: köyhimmänkin mökin omistajalla riitti

18 Siemenlisättyjen taimien ominaisuudet vaihtelevat eikä hedelmien maku ole useinkaan hyvä. Jalontaminen tarkoittaa ominaisuuksiltaan hyväksi tiedetyn puun verson tai silmun liittämistä siemenlisättyyn perusrunkoon. Varhaisissa kirjoissa nykyistä jalontamista kutsutaan usein jalostamiseksi, mutta myös esimerkiksi ymppäämiseksi tai laadunjatkamiseksi. Kirjoissa myös opastettiin valitsemaan siementaimien joukosta todennäköisimmin parhaat yksilöt, ellei mahdollisuutta jalontamiseen ollut.

19 Kasvien vaatimukset esimerkiksi kasvukauden pituuden ja lämpösumman suhteen sekä reagointi lämpötilojen vaihteluihin vaihtelevat suuresti. Siksi lähialueelta peräisin oleva lisäysmateriaali parantaa kasvien menestymismahdollisuuksia. Ks. esim. Schalin 1938, 11-13. 
siihen varallisuutta, koska siemenet ja kasvit olivat edullisia ja niitä saattoi saada myös ilmaiseksi. Suomalaiset kirjoittajat olivat hyvin perillä lukijoiden resursseista ja koristekasvien vähäisestä tarjonnasta, joten monissa teoksissa neuvottiin siirtämään kasveja luonnosta ja esiteltiin kotipihaan sopivia lajeja.

Kauneus kuului siis kaikille, säätyyn, varallisuuteen, ikään ja sukupuoleen katsomatta. Jotkut kirjoittajat katsoivat 1910-luvulla kuitenkin aiheelliseksi muistuttaa, ettei kodin ympäristön koristelussa tarvinnut pyrkiä ylellisyyteen. "Monin paikoin kaikkien kansankerrosten keskuudessa yleiseksi tullut rihkamakoreus" oli todiste asukkaiden maun puutteesta ja kehittymättömästä kauneusaistista; luonnossa ilmenevä ja sen kanssa sopusointuinen kauneus oli sen sijaan oikeanlaista (Hyvönen 1913, 17-18). Tarkoitus oli vain saada kodit kodikkaiksi, että asukkaat viihtyisivät niissä (Salonen ja Kurimo 1915, 88), ja vaatimattomuus ja yksinkertaisuus olivat läheistä sukua kodikkuudelle (Elenius 1915). Kauneuden ja siisteyden nähtiin kulkevan käsi kädessä. Hyvin hoidettu ja siisti, kasvein ja kukkasin somistettu asunnon ympärys oli miellyttävä ja soma, vaikka se olisi vaatimatonkin. Siisteyden ja puhtauden edistäminen olivat etenkin naisille suunnatun kansanvalistuksen painopisteitä esimerkiksi marttatyössä, jonka toimintaan kuului myös puutarhaneuvonta (Ollila 1993, 40-41; Koski 2011, 166-168).

Marttajärjestö antoi myös ohjeistusta sunnuntain oikeanlaiseen viettoon perheen kesken (Ollila 1993, 49). Sunnuntai oli vanhastaan pyhitetty Raamatun käskyn mukaisesti lepopäiväksi. Uskonnollisuuden merkitys yhteiskunnassa väheni 1900-lukua lähestyttäessä, mutta nyt terveysvalistus asetti levolle luonnontieteellisiä perusteita. Lepo oli eri asia kuin veltto laiskottelu: ahkeran työnteon vastapainoksi tarvittiin kunnon lepoa, joka virkisti sekä ruumista että sielua. Sen tuli kuitenkin olla laadultaan tervettä; toisenlaista kuin väkijuomat tai varieté-näytännöt. (Lehtonen 1995, 241.) Puutarha levon paikkana nousee aineistossa esiin 1900-luvun alusta lähtien. Puutarhasta oli lupa nauttia ja siellä sai myös levätä. Puiden siimes oli arvostettua oleskelupaikoissa ja lehtimaja, millä yleisimmin tarkoitettiin puolikaareen istutettuja pensaita, mainittiin lähes kaikissa koristepensaita ja puutarhan suunnittelua käsittelevissä kirjoissa. Lehtimaja oli lepopaikka: sinne sijoitettiin penkki tai pöytäryhmä ja siellä saattoi nauttia kahvikupposen, lueskella, kuunnella lintujen laulua tai viettää lepohetkeä toisten kanssa seurustellen.

\section{Paremmaksi ihmiseksi}

Kauneuden uskottiin jalostavan ja kasvattavan ihmistä, koska kauneuden ymmärtämisestä on seurauksena siisteyden, puhtauden ja järjestyksen rakkaus. Jotkut kirjoittajat olivat kuitenkin sitä mieltä, että erityisesti luonnon kauneuden ymmärtämiseen vaaditaan tietoa. Siksi korkeampaa valistusta seuraa puhtaampi kauneudentaju. (Esim. Reijonen 1927; Schübeler 1884, 13; ks. myös Ollila 1993, 40-41.) Kaunis ja miellyttävä kotiympäristö johti kirjojen mukaan myös muunlaiseen hyvään. Puut, pensaat ja kukkaset pienen, sievän asunnon ympärillä viestivät ohikulkijallekin onnellisesta kodista ja myös asunnon sisäpuolella vallitsevasta siisteydestä ja järjestyksestä. Samalla niiden uskottiin kasvattavan asukkaiden rakkautta kotiin ja sitä kautta myös kiintymystä synnyinseutuun.

Puutarhanhoidon nähtiin lisäävän perheen yhtenäisyyttä, sopusointua ja onnellisuutta. Erityisen paljon niiden merkityksestä perheen hyvinvoinnille puhuttiin 1910-luvulla. Koska puutarhaviljely lisäsi perheen taloudellista hyvinvointia, se suojasi lapsia köyhyydeltä ja kurjuudelta. Se esti heitä myös joutumasta liian aikaisin vieraan palvelukseen, jolloin 
vanhemmat voivat pitää heistä paremmin huolta ja entistä useammat lapset saivat mahdollisuuden käydä koulua. Puutarhassa lapsetkin kykenivät tekemään hyödyllistä ja samalla mieleistä työtä. Puutarhatyötä pidettiin kevyenä, joten se sopi lapsille. Lasten yhteiskunnallisen roolin muuttuminen heijastuu myös kirjoissa: vanhimmissa teoksissa korostuu lasten merkitys työntekijöinä ja se, että nuorena opituista taidoista on heille itselleenkin hyötyä. 1910-luvulta alkaen aletaan puhua enenevästi siitä, kuinka puutarhatyö on lapsista hauskaa ja että he tekevät sitä mielellään.

Kasvitarhaviljelyn merkityksen korostaminen kasvatustyössä on aineistosta erittäin selkeästi erottuva teema. Kansakoulujen kasvitarhaopetuksen puolesta puhuttiin kirjoissa paljon ja lämpimästi aina kansakoulujen vakiintumiseen asti. Kirjoittajat toivoivat, että puutarhatieto saataisiin levitettyä koko maahan nimenomaan koulupuutarhojen ja kansakoulujen kasvitarhaopetuksen avulla. Koulupuutarhat toimisivat esimerkkeinä ympäristölle, ja koulussa lapsena opittua puutarhatyötä haluttaisiin jatkaa vielä aikuisenakin. Sekä puutarha-alan ammattilaiset että koulupuutarha-aatteen ajajat olivat yhtä mieltä siitä, että puutarhatyö on lapsille hyväksi. Puutarhatyön harjoittamisen nähtiin kehittävän ihmisessä monenlaisia henkisiä ominaisuuksia, kuten ahkeruutta, kärsivällisyyttä ja järjestelmällisyyttä, mutta myös suojelevan lapsia pahalta. Joissakin 1800-luvun puolella julkaistuissa kirjoissa korostettiin, että lapset oppivat puutarhatyön avulla ymmärtämään Luojan töitä ja suuruutta, millä kenties pyrittiin myös lieventämään kirkon ja hengellisten liikkeiden kansakoulunvastaisuutta ennen kansakoulujen vakiintumista (ks. Nieminen 2006, 66-83).

Puutarha-alan edustajilla saattoi olla toiveita tulevien ammattilaisten kasvattamisesta, mutta opettajille keskeistä oli puutarhaviljelyn hyödyntäminen kasvatustyössä (esim. Smirnoff 1893, 32; Lindgren [Stening] 1903, 247; vrt. Hyvönen 1913, 12, 28; Luukko 1918, 145). Koulupuutarha kuvattiin monipuolisena opetusvälineenä, jota saattoi hyödyntää eri aineiden opetuksessa. Tärkeintä oli kuitenkin sen elämää varten tarjoama oppi. Koulupuutarha liittyi myös pyrkimykseen uudistaa todellisesta elämästä vieraantunutta koulua vastaamaan paremmin käytännöllisen elämän vaatimuksia (Hyvönen 1913; Luukko 1918). Koulupuutarhan yhtenä tärkeänä tehtävänä oli herättää lapsessa kiinnostusta luontoon ja halua ymmärtää luonnon salaisuuksia. Luonnon havainnoinnin uskottiin herättävän lapsessa ihailua ja myötätuntoa, minkä seurauksena kasveja ei haluta katkoa tai linnunpesiä tuhota. Eläinten hyvä hoito liitettiin muussakin ajan keskustelussa sivistykseen ja eläinsuojeluaate pyrki muuttamaan ihmisten asenteita (Kaarlenkaski ja Piirainen 2014, 14; Nieminen 2001, 9-10). Myötätunto nähtiin osana sivistystä ja ihmisen ajateltiin oppivan puutarhanhoidon avulla suhtautumaan suojelevasti ympäröivään elämään sen kaikissa muodoissa.

Yksi puutarhaviljelyksen eduista oli "joutoaikojen" käyttäminen hyödyllisesti. Ahkeruuteen kasvaminen oli erityisen tärkeää lapsille ja nuorille. Opettajataustaisten kirjoittajien lisäksi monet muutkin totesivat, ettei joutilaisuus ole lapsille hyväksi, vaan se johdattaa heidät huonoon seuraan ja oppimaan tarpeettomia tapoja. Yhteiskuntarakenteen muuttuminen nosti 1900-luvun taitteessa myös teollisuustyöväestön sivistystyön kohteeksi (Koski 2011, 163-165). Koululaisten joutilaisuus kesällä ja kaupunkien työläisten lisääntynyt vapaa-aika olivat huolena etenkin vuonna 1918 julkaistuissa kirjoissa (Luukko 1918; Lundén 1918). Lundén pitää ryhmäpuutarhoja ratkaisuna kaupungistumisen ongelmiin ja tuo esiin niiden yhteiskuntahygieenisen ja kasvatuksellisen merkityksen. Hänen mukaansa työajan lyhentymisellä voitettu aika tulee käyttää luonteiden kehittämistä edistävään työhön, ja terveellisin ja tuottavin paikka työläisille viettää runsastunutta vapaa-aikaansa on oma puutarha. 
Toisaalta lyhentynyt työaika edellytti ehkä tarmokkaampaa työntekotapaakin, minkä vuoksi ryhmäpuutarhapalstalla oli tärkeä merkitys voimien palautumisen paikkana. (Lundén 1918, 17, 21-23.) Saksassa alkunsa saanut siirtolapuutarhatoiminta yleistyi Euroopassa 1800luvun lopulla ja 1900-luvun alussa. Suomen ensimmäiset siirtolapuutarhat perustettiin 1910-luvulla Porvooseen, Tampereelle, Ouluun ja Helsinkiin. Niiden synnyn taustalla olivat teollistumisen ja kaupungistumisen etenkin työväestölle aiheuttamat ongelmat. Porvaristo pyrki ehkäisemään ongelmia ja lisäämään yhteiskunnan vakautta siirtolapuutarhatoiminnan avulla. Viljelijöille olennaista oli viljelyn tuottama konkreettinen hyöty. Samalla siirtolapuutarhatoiminta kuitenkin ohjasi työväestöä kohti porvarillisia arvoja, lisäsi kansalaisten hyvinvointia ja vähensi sosiaalihuollon tarvetta. (Salmela 2001; ks. Ek 1979 ja 1993.)

Puutarhaviljelyn perusteluihin kuului myös raittiuden lisääntyminen ja alkoholin aiheuttamien haittojen vähentyminen. Maata omistavilla viljelijöillä oli vuosina 1800-1865 laillinen oikeus polttaa viljaa viinaksi, ja talonpojille viina oli pääasiallinen tulonlähde viljan ohella. Kotipolttoa kuitenkin vastustettiin ja sitä pidettiin ylempien säätyjen keskuudessa kansantaloudellisena tuhlauksena ja moraalisena ongelmana. (Apo 2001, 86-89.) Puutarhaviljelyksen merkitys raittiuden edistämisessä tuotiin esiin monissa kirjoissa vuoteen 1918 asti, aluksi suosittelemalla marjaviinien valmistamista viljaa tuhlaavan paloviinan polttamisen ja kalliiden ulkomaisten viinien tilalle (Söderberg 1862, 54). Raittiusaatteen nousun myötä sävy muuttui ja taloudellisten syiden sijaan astuivat sosiaaliset perusteet. 1910-luvulla uskottiin myös kasvisten, marjojen ja hedelmien runsaan nauttimisen ehkäisevän väkijuomien väärinkäyttöä ja ihanat hedelmämehut nähtiin varteenotettavaksi kilpailijaksi turmiollisille alkoholijuomille. Lisäksi miellyttävän puutarhan, jossa koko perhe onnellisena puuhaili, oletettiin houkuttelevan perheenisää enemmän kuin savuisen kapakan. (Abelin 1912, 7, 12; Hyvönen 1913, 23; Salonen ja Kurimo 1915, 7; Lundén 1918, 20-21.) Viina nähtiin laajemminkin edistyksen vihollisena 1800-luvun lopussa ja 1900-luvun alussa. Etenkin työväestön alkoholinkäyttö muodosti yleisen uhkakuvan. ${ }^{20}$ Suhde alkoholiin kytkeytyi vahvasti isänmaallisuuteen ja yleiseen siveyteen, ja raittiusliike sai kannatusta kaikissa kansankerroksissa. (Apo 2001, 200-213; Sulkunen 1986.)

Kansan tuli siis sivistyä. Sen tuli kuitenkin pysyä sivistyneistön määrittelemissä raameissa ja yhteiskuntajärjestyksen täytyi säilyä (Ollila 1993, 46-51). Puutarhanhoito ohjasi kansaa siveellisyyteen - sivisti - vahvistamalla ihmisessä toivottuja ominaisuuksia ja karsimalla ajan mittaan kaiken raa'an ja epäpuhtaan pois inmisestä. Sivistys oli ymmärrystä ja taitoa hyödyntää luonnon antimia ja nauttia niistä. Myös puutarhan kauneus jalosti ja kasvatti ihmistä. Sanat siveellisyys ja siveys viittaavat tutkimusaineistossa ensisijaisesti moraalisuuteen ja eettisyyteen, mutta myös yhteiskunnalliseen vastuuseen, kuten yleensäkin 1800-luvulla ja 1900-luvun alussa. Taustalla oli ajatus siitä, että yksilöllinen hyvä on kytköksissä yhteiseen ja yleiseen hyvinvointiin, jolloin molempia hyödyttävä toiminta on siveellistä. Epäsiveellistä puolestaan on ihmiskunnan kehitystä estävä tai sitä alemmalle asteelle painava toiminta, kuten epärehellisyys, laiskuus ja juoppous. Ulkoisten tapojen ohella ovat merkityksellisiä tekojen taustalla olevat motiivit ja omantunnon ohjeiden noudattaminen. Siveyteen liitettiin myös kristillisiä arvoja etenkin Snellmania seuranneiden fennomaanien keskuudessa. (Pulkkinen ja Sorainen 2011; Snellmanin ajattelusta ks. Rantala 2013.) holinkulutuksesta kotipolton aikaan, mutta vanhat juomatavat olivat ristiriidassa uusien elämäntapojen ja työaikasäännösten kanssa. Ks. Apo 2001, 204-205; Sulkunen 1986, 22-24, 273, 276-277. 


\section{Puutarhapuheen sävyjä}

Tutkimusaineistosta hahmottuu tarkastelussa erilaisia puhetapoja, jotka olen nimennyt valistus-, sivistys- ja elinkeinodiskurssiksi. Valistuksen ja sivistyksen voi nähdä viittaavan erilaisiin käsityksiin yksilön ja yhteiskunnan suhteista sekä lukeneiston roolista niiden luomisessa. Tällöin valistuneisuus tarkoittaa sellaisen käytännöllisen tiedon omaamista, jolla on mahdollista selviytyä arkipäivän aineellisista ongelmista. Tarpeellisiksi katsotut tiedot ja taidot määrittelee lukeneisto; valistuksen kohteen laajemman ymmärryksen kasvattamista ei tavoitella. Sivistys sen sijaan tarkoittaa parempaa ja syvällisempää ymmärrystä, kulttuurista tietoisuutta, jota vasten on mahdollista hankkia uutta tietoa ja myös arvioida omien tekojen henkistä ja yhteisöllistä merkitystä. Sivistämisessä on siis kyse kansalaiskasvatuksesta, tietoisesta aktiivisten ja yhteiskuntaan osallistuvien ihmisten kasvattamiseen pyrkivästä toiminnasta. Sitä voivat tehdä monet tahot, esimerkiksi järjestöt, mutta erityisesti se kytkeytyy koulujärjestelmän toimintaan. (Nieminen 2006, 178-180; Karkama 2001, 95-96; Arola 2003, 4-5; ks. myös Kemppainen 2013.)

Valistuksen ja sivistyksen kohteita lähestytään erilaisen retoriikan avulla: eri yleisöille puhutaan eri asioista ja erilaisin sanakääntein. Puutarhakirjojen valistusdiskurssi keskittyi käytännön ohjeiden ja viljelyn perustietojen jakamiseen. Sen tavoitteena oli lisätä kotien puutarhaviljelyä, pääasiassa hyötykasvien kasvatusta. Kansa tuli saada myös käyttämään kasviksia, joten kirjat sisälsivät yleensä myös ruoka- ja säilöntäohjeita (erik. Smirnoff 1904; Salonen ja Kurimo 1915; Abelin 1912; Schübeler 1884) tai lyhyitä käyttötapojen esittelyjä etenkin vihannesten kasvatusohjeiden ohessa (esim. Genetz 1894; Lundén 1921). Lisäksi niissä annettiin neuvoja kasvisten varastointiin. Valistusdiskurssin puhunnassa korostuivat puutarhaviljelyn taloudellinen hyöty kodeille, ruoan riittävyys sekä kasvisten terveellisyys ravintona. Varhaisissa kirjoissa viljelylle esitettiin usein myös sivistyksellisiä perusteita, mutta perustelujen painopiste ei silti ollut sivistyksessä. Kansan keskuuteen tietoa levitettiin erityisesti pienten, "helppohintaisten" kirjojen avulla, jollaisia olivat myös kansakoulun oppilaiden kirjat.

Myös sivistysdiskurssi, joka alkaa erottua 1900-luvun taitteessa, pyrki kansan elinolojen parantamiseen, mutta sen kasvatukselliset tavoitteet olivat selkeät. Se suuntasi ohjeensa erityisesti seminaarien ja muiden oppilaitosten opiskelijoille, mutta myös muulle valistuneelle lukijakunnalle. Kasvatusalan ammattilaisille puutarha oli ensisijaisesti kasvatusväline, joka auttoi lapsia kehittymään oikeanlaisiksi aikuisiksi. Tämän ohella puutarhan tuottama aineellinen hyöty toimi kansan ja kansakunnan hyvinvoinnin lisääjänä ja välillisesti myös sivistystason nostajana. Lasten välityksellä maaseudun koteihin tuotu kasvitarhaviljely saattoi olla ensi askel myös muun valistuksen vastaanottamiseen. Puutarhaviljelyn kasvatukselliset perustelut vähenivät 1920-luvulta alkaen kansakoulujen vakiinnuttua ja kotipuutarhaviljelyn yleistyttyä, jolloin puutarhanhoidosta tuli yhä useamman harrastus tai omavaraisuuden lisäämiskeino. Lisäksi sivistyspuheen vähenemiseen vaikutti epäilemättä yhteiskunnallinen muutos: kansaa ei enää holhoavasti ohjattu yhteiskunnan ylätasolta käsin, ja myös kirjoissa voimakas sivistyspuhe päättyy vuoteen 1918 (Lundén 1918; Luukko 1918). Puutarhaviljelyn perustelusta tuli asiakeskeistä ja suostuttelussa alettiin enenevästi vedota yksilölliseen hyvinvointiin.

Puutarhan tuottama taloudellinen hyöty on aineiston keskeinen teema. Kotitarveviljely edisti perheen taloudellista hyvinvointia ja sivistykseen kuului porvarillisten ja protestanttisten arvojen mukainen vastuun ottaminen omasta ja yhteiskunnan taloudesta. Kolmantena 
puhetapana erotan silti elinkeinodiskurssin, jonka keskeinen piirre oli taloudellisen hyödyn painottaminen. Esimerkiksi Smirnoffin hedelmänviljelykirjassa (1893) näkökulma oli rahalliseen tuottoon keskittyvä: tavoitteena oli saada hedelmänviljelystä maahamme tuottava elinkeino. Hedelmäpuista ja marjapensaista saatiin hyötyä myymällä niiden satoa; hedelmien ja marjojen etuja kansan ravitsemukselle kirjoittaja ei mainitse. Puutarha-alan ammattilaisille puutarha oli tuotantoväline, joka haluttiin saada mahdollisimman toimivaksi, joten siitä pyrittiin hankkimaan ja jakamaan mahdollisimman paljon tietoa. Elinkeinodiskurssia edustavat myös erikoistunutta tietoa sisältävät kirjat, joissa perusteluja puutarhaviljelylle esitettiin vain vähän tai ei ollenkaan. Tähän ryhmään kuuluvat myös hakuteokset, jotka olen jättänyt aineiston ulkopuolelle. Elinkeinodiskurssi alkaa hahmottua jo 1800-luvun puolella, mutta valtadiskurssi siitä tuli 1920-1930-luvulla, kun alan tutkimus- ja koetoiminta oli päässyt käyntiin. Sekä ammatti- että kotipuutarhaviljely yleistyivät ja puutarhaviljelystä tuli pientilojen varteenotettava sivuelinkeino. Lisäksi 1920-luvun alusta 1940-luvun alkuun kestänyt ilmastollisesti suotuisa jakso edisti maatalouden ohella myös puutarhaviljelyä (Niemelä 2008 , 9). Tarve perustella puutarhaviljelyn tarpeellisuutta väheni; olennaista oli tiedon jakaminen kohderyhmälle sopivalla tavalla.

Nimeämäni diskurssit eivät ole luokittelujärjestelmä, vaan tapa hahmottaa lukijoille kirjojen avulla välitettyä sanomaa. Aineisto on vain osa kaikesta tarkastelujaksolla julkaistusta kirjallisuudesta eikä oikeuta tekemään johtopäätöksiä yksittäisten kirjoittajien ajatusmaailmasta. Silti kirjoittajien taustoilla ja väestön olosuhteiden tuntemuksella voi aavistaa olleen vaikutusta puhetapaan ja painotuksiin. Yksittäiset kirjoittajat eivät kuitenkaan olleet lähtökohtaisesti yhden diskurssin edustajia, vaan viestiin vaikutti se, puhuttiinko kotitarveviljelystä, koulupuutarhasta vai elinkeinosta sekä se, kenelle ja milloin puhuttiin.

\section{Tavoitteena hyvinvoiva kunnon kansalainen}

Olen tässä artikkelissa tarkastellut 1860-1930-lukujen puutarhapuhetta ja puutarhakirjoissa ilmaistuja perusteluita puutarhaviljelylle. Puutarhavalistuksen lähtökohtana voidaan pitää omatoimisen ruoantuotannon tuottamaa taloudellista ja terveydellistä hyötyä, joka lisäsi väestön hyvinvointia. Monissa kirjoissa todettiin kansan kuitenkin olevan vastahakoista ottamaan vastaan uusia ajatuksia ja opettelemaan uusien ravintoaineiden käyttöä (esim. Schübeler 1884, 8; Hyvönen 1913, 56; Salonen ja Kurimo 1915, 9). Ensimmäiset positiiviset kommentit hedelmän- tai kasvitarhaviljelyn viriämisestä maassamme esitettiin silti jo 1800-luvun lopulla, ja koko tarkastelujakson ajan mainittiin usein "ilahduttavaa edistymistä" tapahtuneen (esim. Smirnoff 1893, 3, 8; Heikel 1919, VIl; Hyvönen 1918, 4; Salonen 1925, 7; Salonen 1935, 7). Lähes samaan hengenvetoon kuitenkin myös todettiin asiaa lyötävän yleisesti laimin. Vielä 1930-luvullakin puu- ja kasvitarhaviljelys oli "vasta alkuasteellaan" (Kalervo 1931, 3; Salonen 1935, 7) ja "varsin rajoitettua" (Lehtonen 1934, 5). Syy hitaaseen edistymiseen kuitenkin muuttui ajan kuluessa: vanhimmissa teksteissä syinä pidettiin kansan tietämättömyyttä, epäluuloja, uusien asioiden vastustusta ja huonoja elinoloja, 1920-luvulta lähtien taas lähinnä tiedon puutetta.

Puutarhaviljelyn edistämiseen käytettiin kirjoissa monenlaisia keinoja: esitettiin rationaalisia syitä ja vedottiin tunteisiin. Niissä tuotiin esiin kansan kurjat elinolot ja osoitettiin epäkohdat, kuvattiin valoisampaa ja taloudellisesti vakaampaa tulevaisuutta sekä lukijalle että tuleville polville, houkuteltiin nautinnoilla ja vedottiin edullisuuteen ja helppouteen. Puutarha oli työväline, jota tarjottiin kaikille, myös varattomille. Viljelyharrastusta uskottiin 
herätettävän parhaiten opettamalla ihmisiä kasvattamaan ensin sellaisia kasveja, joista saatiin suurin hyöty. Puutarhaviljelystä ei asetettu poikkiteloin maatalouden, vakiintuneiden sukupuoliroolien tai uskonnon kanssa: sen ei tarvinnut viedä työvoimaa, hyvää viljelymaata tai lannoitteita maanviljelykseltä eikä se ollut yksin miesten tai naisten asia. Avain onneen oli pala omassa hallinnassa olevaa maata ja sen viljelyyn tarvittavat alkutiedot. Lapsikin pystyi siihen, ja lasten omien pienten kotipuutarhapalstojen avulla voitiin käytännössä osoittaa puutarhaviljelyksen hyöty myös vanhemmille. Lapset siis valjastettiin sivistystyön välikappaleiksi. Kotoa tai koulusta omaksuttu puutarhanhoitotaito oli pääomaa, josta oli lapselle hyötyä koko elämän ajan ja joka samalla vahvisti kansakunnan yhtenäisyyttä kasvattamalla lapsista kunnon kansalaisia. Puutarha myös sitoutti ihmistä paikkaan ja kasvatti isänmaallisuutta. Nousevassa nuorisossa oli saatava heräämään maahenki, sillä "[e]llei kansan elämä perustu voimaperäiseen kannattavaan maanviljelykseen, on sen tulevaisuus synkkä" (Kalervo 1912, 79).

Kirjoittajien mukaan puutarhanhoito tarjosi vakautta ihmisten elämään lisääntyneiden elintarvikkeiden muodossa. Mahdollisuus turvata perheen toimeentuloa ja ruoan saantia oman työn avulla auttoi ihmisiä katsomaan tulevaisuuteen aiempaa toiveikkaammin. Puutarha koristekasveineen tuotti lisäksi iloa elämään ja lisäsi siten kansan tyytyväisyyttä ja hyvinvointia. Viljelyn saattoi aloittaa vähinkin tiedoin, mutta tieto ja taito lisäsivät onnistumisen mahdollisuuksia, mikä oli tärkeää viljelyinnon sytyttämiseksi ja ylläpitämiseksi. Puutarhaviljelyn aloittaminen oli mahdollista lähes jokaiselle maatilkun haltijalle. Panokseksi vaadittiin ainoastaan omaa työtä, johon saattoi käyttää pienetkin joutohetket ja joka oli itsessäänkin virkistävää ja mielihyvää tuottavaa. Puutarhaviljelyn avulla jokainen saattoi ottaa osaa myös yleisen hyvinvoinnin lisäämiseen kasvattamalla maan omavaraisuutta.

Kotipuutarha tai puutarhapalsta tarjosi myös pääsyn aiemmin vain ylemmille sosiaaliryhmille varattuihin nautintoihin, kuten herkullisiin hedelmiin. Itse kasvatetut tuotteet olivat - kirjaimellisestikin - oman työn hedelmiä, "viatonta" ylellisyyttä, jonka saattoi suoda kansalle huoletta. Itse kasvattamiaan puutarhan antimia nauttiva kansalainen osasi varmasti antaa niille myös arvoa, koska tiesi niiden hankintaan käytetyn työn määrän. Puutarha toimi kansan kasvattajana omalla olemuksellaan, koska se paljasti huolimattomuuden ja laiskuuden, mutta palkitsi ahkeruuden ja hyvin tehdyn työn runsain mitoin. Puutarha sijoittui kodin ympärille ja näkyi siten kaikille ohikulkijoille. Olemuksellaan se viestitti, millaisia ihmisiä asunnossa asui. Vaatimaton mökki, jonka ympäristö oli siisti ja pieni kasvimaa hyvin hoidettu, välitti muille ihmisille viestin köyhistä, mutta silti kunnollisista asukkaista. Näin puutarha toisaalta toimi sosiaalisen erottelun välineenä, mutta tarjosi samalla myös varattomille keinon osoittaa julkisesti kuuluvansa "hyvien", sivistyneiden ihmisten joukkoon.

Näen kirjojen sisältämän sivistyspuheen kasvatustavoitteena tyytyväisen kansalaisen, joka on sisäistänyt valistajien tarpeellisiksi katsomat arvot, tekee velvollisuutensa ja kantaa vastuunsa. Koti ja perhe ovat hänelle tärkeitä, ja hän elää sovussa itsensä ja ympäristönsä kanssa. Hän tyytyy asemaansa yhteiskunnassa eikä aiheuta häiriötä, mutta pyrkii aktiivisesti parantamaan elinolojaan positiivisin keinoin ja tekemään omasta ja perheensä elämästä mahdollisimman hyvän. Hän omaa hyödyllisiä tietoja ja taitoja, on vastaanottavainen ja osaa hyödyntää olemassa olevia resursseja monipuolisesti. Hän voi fyysisesti ja henkisesti hyvin, on siisti ja järjestelmällinen, raitis, tunnollinen, huolellinen ja ahkera eikä pelkää ruumiillista työtä. Hän osaa nauttia kauneudesta ja luoda ympärilleen viihtyisyyttä ja kodikkuutta, mutta pysyy sivistyneistön määrittelemän hyvän maun rajoissa. 
Kansanvalistustyön yhtenä piirteenä voi pitää välineellistämistä, valistuksen konkreettisen sisällön valjastamista muiden pyrkimysten palvelukseen. Vaikka itse neuvonnan sisältö ei välttämättä muuttunut paljoakaan ajan kuluessa, saattoivat siihen kytkeytyvät tavoitteet sen tehdä (ks. esim. Ollila 1993, 144, 239). Kukin kirjoittaja painotti asioita oman ideologiansa mukaisesti; jokainen kirja oli puheenvuoro keskusteluun, jota suomalaisen puutarhaviljelyksen ympärillä käytiin ja jonka avulla sitä kehitettiin. Puutarhavalistajien toiminnan taustalla on ollut erilaisia vaikuttimia, joiden tarkasteluun ei tässä artikkelissa ole tilaisuutta. Huoli kansan tilasta oli kuitenkin yksi motiivi, ammatillinen kiinnostus alan mahdollisuuksiin maassamme toinen. Kirjoittajien taustojen ja toiminnan tarkempi tutkiminen olisi kiinnostavaa muun muassa siksi, että puutarhakirjojen kirjoittajat olivat aktiivisia toimijoita monella saralla ja heidän joukkonsa muodostui sekä miehistä että naisista, toisin kuin esimerkiksi täysin miesvaltaisen maatalousvalistuksen saralla. Erityisen kiehtovaksi puutarha-alan kehityksen tekee se, että alan varhaiset toimijat olivat todellisia edelläkävijöitä pyrkiessään juurruttamaan maahan täysin uutta elinkeinoa ja toimeentulon lähdettä. Heidän työtään ja kirjoituksiaan leimaa palava halu viedä asiaa eteenpäin sekä luja usko sen tarjoamiin mahdollisuuksiin - vastoinkäymisistä huolimatta.

\section{Tutkimusaineisto julkaisuajankohdan mukaan järjestettynä}

Eneroth, Olli [Olof] 1860. Kaswutarha-kirja Rahwaalle: Kaswutarha-kirja Rahwaan hyödyksi. Suomentanut F. v. P. Turku: J. W. Lilljan kirjapaino.

Söderberg, C. G. 1862. Hedelmäpuiden ja Marjapensasten kaswattamisesta. Suom. K. K. Helsinki: Theodor Sederholm.

Holm, J. F. 1875. Ruoka-kaswiston hoidanta: Sisältäwä ruokakaswistojen perustamisen ja hoitamisen ynnä meidän ilmastollisiin oloihin sopiwain ruokakaswien, marjapensasten ja hedelmäpuiden wiljelemisen. Toisesta painoksesta suomentanut Samuel Roos. Tieteellinen ja paranteellinen tohtori. Helsinki: G. B. Edlund.

Schübeler, F.C. 1884. Kasvitarha: Sen hyöty ja arvo taloudessa. Toisesta norjalaisesta painoksesta mukailemalla suomentanut Arvid Th. Genetz. Sortavala: C. W. Alopæus.

Smirnoff, A. [Alexandra]. 1893. Puuhedelmien wiljelemisesta Suomessa sekä käytännöllisiä neuwoja wasta-alkawille. Kansanvalistus-seuran toimituksia LXXXII, Yhdeksästoista wuosikerta. Ensimmäinen wihko. Helsinki: Kansanvalistus-seura.

Genetz, Arvid Th. 1894. Kansan ja kansakoulun kasvitarhakirja. Porvoo: Werner Söderström.

Lindgren, Erik. 1903. Kasvitarhakirja: Neuvoja keittiökasvien, hedelmäpuiden, marjapensasten, puistopuiden ja -pensaiden, ulkoilma- ja huonekukkien viljelemiseen, ohjeeksi jokaiselle kasvitarhanhoidon harrastajalle. Seitsemännestä tarkastetusta ja lisätystä painoksesta Suomen oloihin mukaillut Klas Stening, Mustialan puutarhuri. Suomentaneet K. Korpela, pitäjän apulainen ja Aug. Viksten, kansak. opettaja. Porvoo: Werner Söderström.

Smirnoff, Alexandra. 1904. Käsikirja yksinkertaisessa puutarhanhoidossa kansaa varten. Martta-yhdistyksen kirjasia. Suomensi Alli Nissinen. Toinen painos.

Relander, O. 1905. Puutarhakirja kansakouluja varten. Porvoo:Werner Söderström Osakeyhtiö.

Smirnoff, Alexandra. 1910. Kukkaistarhan hoito: Käsikirja monivuotisten kukkakasvien viljelemisestä ulkosalla. Ulkomaalaisten teosten mukaan toimittanut Alexandra Smirnoff. Porvoo: Werner Söderström Osakeyhtiö. 
Abelin, Rudolf. 1912. Pikkupuutarha: Neuvoja hedelmäpuiden, marjapensasten, keittiö- ja koristekasvien viljelemiseen ja hoitoon. Suomen oloihin sovittaneet B. W. Heikel ja Ossian Lundén. Suomentanut Aug. Heliä.Toinen, korjattu painos. Helsinki:Kustannusosakeyhtiö Otava.

Kalervo, Kalle. 1912. Kaikille kasviksia ja hedelmiä: Kansa puu- ja kasvitarhaviljelystä harjoittamaan. Porvoo: Werner Söderström Osakeyhtiö.

Lundén, Ossian. 1912. Kotipuutarhan Työkalenteri: Muistilistoja Suomen puutarhanviljelijöille ja kukkasystäville. Suomennos. Helsinki: Kustannusosakeyhtiö Otava.

Vanamo, Kaarlo. 1912. Keittiökasvien viljelys: Opas alotteleville. Hämeenlinna: Arvi A. Karisto.

Hyvönen, M. [Matti]. 1913. Koulupuutarha: Käsikirja koulupuutarhan perustamista ja hoitoa varten. Helsinki: Kustannusosakeyhtiö Otava.

Hyvönen, M. [Matti]. 1914. Kotipuutarhuri: Käytännöllinen opas keittiökasvien, hedelmä- ja marjakasvien sekä kaunistekasvien hoitajille. Helsinki: Kustannusosakeyhtiö Otava.

Elenius, Edvard. 1915. Kotiemme kauneus: Asuinrakennukset, huoneiden sisustus, puutarha. Kansanvalistusseuran käsiteollisuuskirjasto 17. Helsinki: Kansanvalistusseura.

Salonen, Frans ja Anna Kurimo. 1915. Kotien puutarhakirja ja lyhyt säilöönpano-opas: Ohjeita keittiö-, marja-, hedelmä- ja koristekasvien viljelyyn ja hoitoon sekä kasviksien säilyttämiseen. Terveyden kirjasia n:o 8. Salo: "Terveys".

Parikka, Matti. 1917. Luonnonkasvit kotien kaunistuksena: Neuvoja niiden ystäville. Jyväskylä: J. K. Gummerus Osakeyhtiö.

Hyvönen, M. [Matti]. 1918. Nuorten puutarhakirja: Oppi-ja lukukirja kouluja ja koteja varten. Toinen painos. Helsinki: Kustannusosakeyhtiö Otava.

Lundén, Ossian. 1918. Ryhmäpuutarhoja: Ryhmäpuutarhoista, niiden merkityksestä yhteiskunnassa, niiden perustamisesta ja hoidosta. Suomentanut Helmi Krohn. Helsinki: Kustannusosakeyhtiö Otava.

Luukko, H. V. 1918. Sydänjuuret maahan! Koulukasvitarhat kansantaloudellisina ja pedagoogisina kasvatusvälineinä. Tampere: Suomen Koulukasvitarha-yhdistys.

Heikel, B. W. 1919. Hedelmän- ja marjanviljelys avomaalla. Toinen, lisätty painos. Helsinki: Kustannusosakeyhtiö Otava.

Elfving, Jenny. 1921. Kukkaviljelys avomaalla: Yksi- ja kaksivuotiset kukat sekä avomaata varten viljeltävät ruukkukasvit. Helsinki: Kustannusosakeyhtiö Otava.

Lundén, Ossian. 1921. Keittiökasvikirja: Suomen puutarhureita ja puutarhaopetusta varten. Toinen, lisätty ja korjattu painos. Suomentaneet Maiju Pöyhönen ja Ilmari Ahma. Helsinki: Kustannusosakeyhtiö Otava.

Kalervo, Kalle. 1923. Nuori tarhuri: Kansakoulun kasvitarhanhoidon oppikirja. Toinen painos. Helsinki: Osakeyhtiö Valistus.

Karlsson, Richard. 1924. Kodin kukkastarha: Opas monivuotisten, ruohovartisten koristekasvien viljelyksessä, käytännössä ja lisäämisessä. Porvoo: Werner Söderström Osakeyhtiö.

Kalervo, Kalle. 1925. Käytännöllinen puutarhanhoito: Puutarhanhoidon opas sekä yksityistarvetta että seminaareja, maamies- ja emäntäkouluja, kansanopistoja ja kesäkursseja varten. Toinen painos. Helsinki: Kustannusosakeyhtiö Kirja.

Salonen, Frans. 1925. Keittiökasvien ja marjain viljelys: Puutarhanhoidon opetusta ja itseopiskelua varten. Porvoo: Werner Söderström Osakeyhtiö. 
Pöyhönen, Nora ja Maiju Pöyhönen. 1927. Kodin kasvitarha: Opas keittiökasvien, marjain, hedelmien, koristepuiden ja-pensaiden, avomaan kukkien ja huonekasvien viljelemiseen. Helsinki: Kustannusosakeyhtiö Otava.

Reijonen, Annikki. 1927. Puutarhakauneus: Taiteellisia näkökohtia ja käytännöllisiä viitteitä sen luomiseksi. Porvoo: Werner Söderström Osakeyhtiö.

Collan, Olavi. 1929. Hedelmän- ja marjanviljelyksen käsikirja. Helsinki: Kustannusosakeyhtiö Otava.

Ignatius, Gustaf. 1929. Lyhyt puutarhanhoidon oppikirja kansakoulun jatko-opetusta varten. Porvoo: Werner Söderström Osakeyhtiö.

Jortikka, Mikko. 1929. Koti- ja huvilapuutarhat: Perustaminen, istutus, lannoitus ja maanjärjestelyt kemiallisia ja kasvifysiologisia seikkoja silmälläpitäen. Helsinki: Kirjaosakeyhtiö Tieto.

Kalervo, Kalle. 1931.Käytännöllisiäohjeitapuutarhanhoitajille. Helsinki:Suomen puutarhurien kauppayhtiö ja siemenkauppa Hortus Oy.

Collan, Olavi. 1933. Kodin hedelmätarha:Sen perustaminen ja hoito sekä tuotteiden talteenotto, säilytys ja jalostaminen. Helsinki: Otava.

Salonen, Frans ja K. Jaatinen. 1933. Kodin puutarha. Porvoo: Werner Söderström Osakeyhtiö.

Lehtonen, Väinö. 1934. Puutarhakirja maatalouskouluja ja itseopiskelua varten. PorvooHelsinki: Werner Söderström Osakeyhtiö.

Salonen, Frans. 1935. Aikainen vihannesviljelys: Lasin alla ja avomaalla. Porvoo-Helsinki: Werner Söderström Osakeyhtiö.

Schalin, Bengt. 1938. Koristepensaista kauneimmat. Porvoo-Helsinki: Werner Söderström Osakeyhtiö.

\section{Kirjallisuus}

Alanko, Pentti. 2005. "Lundén, Ossian." Kansallisbiografia-verkkojulkaisu. Studia Biographica 4. Helsinki: Suomalaisen Kirjallisuuden Seura, 1997- (viitattu 17.6.2019). http://urn.fi/ urn:nbn:fi:sks-kbg-005816.

Alanko, Pentti. 2007. "Vanamo, Kaarlo." Kansallisbiografia-verkkojulkaisu. Studia Biographica 4. Helsinki: Suomalaisen Kirjallisuuden Seura, 1997- (viitattu 17.6.2019). http://urn.fi/ urn:nbn:fi:sks-kbg-008480.

Alanko, Pentti ja Pirkko Kahila. 1994. Ukonhattuja ahkeraliisa:Perinteiset hyöty-ja koristekasvit. Helsinki: Kustannusosakeyhtiö Tammi.

Alanko, Teija. 2018. Malvaja mulperi:Poimintoja entisajan puutarhoista. Helsinki:Suomalaisen Kirjallisuuden Seura.

Alapuro, Risto, Ilkka Liikanen, Kersti Smeds ja Henri Stenius (toim.). 1987. Kansa liikkeessä. Helsinki: Kirjayhtymä.

Apo, Satu. 2001. Viinan voima: Näkökulmia suomalaisten kansanomaiseen alkoholiajatteluun ja-kulttuuriin. Helsinki: Suomalaisen Kirjallisuuden Seura.

Arola, Pauli. 2003. Tavoitteena kunnon kansalainen: Koulun kansalaiskasvatuksen päämäärät eduskunnan keskusteluissa 1917-1924. Helsinki: Helsingin yliopisto. https://helda. helsinki.fi/handle/10138/19795. 
Bonsdorff, Gabriel von. 2010. Keittiökasveja kotitarpeeseen: Brinkhallin puutarhaopas 1804. Sisältää teoksen Brinkhallin keittiöpuutarhaopas, eli, Lyhykäisiä tietoja siitä miten perustetaan keittiöpuutarha kotitarpeisiin ja siitä kuinka siinä sopivimmalla tavalla voidaan viljellä erilaisia ravinnoksi kelpaavia kasveja ynnä miten niitä säilötään ja hyödynnetään. Suomentanut ja toimittanut Irma Lounatvuori. Helsinki: Suomalaisen Kirjallisuuden Seura.

Fennica. Suomen kansallisbibliografia. https://fennica.linneanet.fi/.

Donner, Julia. 2015. Kasvitarhasta puutarhakotiin: Naiset kotipuutarhan tekijöinä Suomessa 1870-1930. Helsinki: Helsingin yliopisto. https://helda.helsinki.fi/handle/10138/158235.

Gadd, Pietari Adriani [Pehr Adrian]. 1768. Lyhykäinen Ja Yxikertainen Neuwo Kuinga Krydimaan Yrttein Kaswannot, Suomen Maasa, Taittaan saatetta tuleundumaan. Turku: J. C. Frenckell. http://s1.doria.fi/helmi/bk/rv/fem970239/.

Ek, Sven B. 1979. Kolonis sista strid. Göteborg: Etnologiska föreningen i Västersverige.

Ek, Sven B. 1993. Kolonin. Stockholm: Carlssons.

Haapanen, Arvo, Olavi Collan ja S. S. Salmenlinna. 1935. Lepaan puutarhaopisto 1910-1935. Porvoo: Werner Söderström Osakeyhtiö.

Hakapää, Jyrki. 2008. Kirjan tie lukijalle: Kirjakauppojen vakiintuminen Suomessa 1740-1860. Helsinki: Suomalaisen Kirjallisuuden Seura.

Halme, Anna-Maija (toim.). 2005. Puistot ja puutarhat: Suomalainen puutarhaperinne. Parker och trädgårdar: Finländsk trädgårdstradition. Helsinki: Suomen Kotiseutuliitto.

Helsti, Hilkka, Laura Stark ja Saara Tuomaala (toim.). 2006. Modernisaatio ja kansan kokemus Suomessa 1860-1960. Helsinki: Suomalaisen Kirjallisuuden Seura.

Häkkinen, Antti, Vappu Ikonen, Kari Pitkänen ja Hannu Soikkanen. 1991. Kun halla nälän tuskan toi: Miten suomalaiset kokivat 1860-Iuvun nälkävuodet. Helsinki: Werner Söderström Osakeyhtiö.

Häyrynen, Maunu, Taneli Eskola, Satu Frondelius ja Pekka Leskinen (toim.). 2001. Hortus Fennicus: Suomen puutarhataide. Helsinki: Viherympäristöliitto ry ja Puutarhataiteen seura ry.

Jussila, Tuomas ja Lari Rantanen (toim.). 2018. Nälkävuodet 1867-1868. Helsinki: Suomalaisen Kirjallisuuden Seura.

Kaarlenkaski, Taija ja Marjukka Piirainen. 2014. "Hyötyä ja hyvinvointia kansalle. 1800-1900-lukujen vaihteen puutarhan- ja karjanhoidon opaskirjat aineistona." Elore 21(2): 1-22. Joensuu: Suomen kansantietouden tutkijain seura ry. https://doi. org/10.30666/elore.79155.

Karkama, Pertti. 2001.Kansakunnan asialla:Elias Lönnrotja ajan aatteet. Helsinki:Suomalaisen Kirjallisuuden Seura.

[Keldán, Anton Gustaf] A. G. K-n. 1871. Kansakouluille huoneista, kaluista, kaswintarhasta y. m. sekä Luettelo kirjastoja varten. Viipuri: Viipurin suomalainen kirjallisuusseura. http:// urn.fi/URN:NBN:fi-fd2016-00009910.

Kemppainen, Mikko. 2013. "Martta - tiedon ja valon tuoja: Kansalaiskasvatus marttayhdistyksen Emäntälehdessä 1900-luvun alussa ja 2000-luvulla." Aikuiskasvatus 33(3): 177-189.

Kersalo, Juha ja Pentti Pirinen. 2009. Suomen maakuntien ilmasto. Helsinki: Ilmatieteen laitos. https://helda.helsinki.fi/handle/10138/15734. 
Kivistö, Sari. 2013. "Oppaita ja käytännön tietokirjoja." Teoksessa Suomennetun tietokirjallisuuden historia 1800-luvulta 2000-luvulle, toimittaneet Outi Paloposki ja H. K. Riikonen, 532-551. Helsinki: Suomalaisen Kirjallisuuden Seura.

Koski, Leena. 2011. "Sivistystyön ihmiskäsitys: villi-ihmisestä aikuiseksi yksilöksi." Teoksessa Valistus ja koulunpenkki: Kasvatus ja koulutus Suomessa 1860-luvulta 1960-luvulle, toimittaneet Anja Heikkinen ja Pirkko Leino-Kaukiainen, 159-183. Helsinki: Suomalaisen Kirjallisuuden Seura.

Koskimies, Tiina. 2009. Patruunan puutarha ja työmiehen kessupenkki. Helsinki: Kustannus Oy Arkki.

Koskimies, Tiina. 2011. Kaunokainen ja ilonpisara: Kotipihojemme kukkien kulttuurihistoriaa. Helsinki: Kirjapaja.

Koskimies, Tiina ja Maarit Knuuttila. 2007. Pappilan puutarhassa: Kasveja ja kulttuurihistoriaa. Helsinki: Kustannus Oy Arkki.

Kuka kukin on. (Aikalaiskirja) 1954. Henkilötietoja nykypolven suomalaisista. Helsinki: Kustannusosakeyhtiö Otava. http://runeberg.org/kuka/1954/.

Kuopion Hippakunnan Sanomia no 20, 12.11.1859. http://digi.lib.helsinki.fi/sanomalehti/ secure/showPage.html?conversationld=4\&action=entryPage\&id=61286.

Laaksonen, Pekka ja Sirkka-Liisa Mettomäki (toim.). 1994. Metsä ja metsänviljaa. Helsinki: Suomalaisen Kirjallisuuden Seura.

Lagerström, Tomas. 2018. Sveriges zonkarta för vedartade växter. Faktablad om ekologisk odling nr 41. Täby: Riksförbundet Svensk Trädgård. http://www.tradgard.org/kunskap/ kunskapsbank/faktablad.html.

Laitinen, Erkki. 2012. "Luontoistaloudesta kaupalliseen metsätalouteen (1850-1950)." Teoksessa Ihminen ja metsä - kohtaamisia arjen historiassa, toimittanut Heikki RoikoJokela, 15-204. Helsinki: Metsäkustannus Oy.

Lehtonen, Turo-Kimmo. 1995. "Bakteerit ja henkisten ruttotautien siemenet: Puhdas elämä suomalaisessa terveysvalistuksessa 1890-luvulla." Teoksessa Terveyden lähteillä: Länsimaisten terveyskäsitysten kulttuurihistoriaa, toimittaneet Timo Joutsivuo ja Heikki Mikkeli, 205-252. Helsinki: Suomen Historiallinen Seura.

Leskinen, Anni. 2007. Kansakoulun kasvitarha- ja maatalousopetukseen liitetyt ihanteet ja tavoitteet 1898-1939. Suomen historian pro gradu -tutkielma. Joensuu: Joensuun yliopisto. http://epublications.uef.fi/pub/URN NBN fi joy-20080002/.

Lindgren, Erik. 1918. Kasvitarhakirja: Neuvoja keittiökasvien, hedelmäpuiden, marjapensasten, puistopuiden ja -pensaiden, ulkoilma- ja huonekukkien viljelemiseen, ohjeeksi jokaiselle kasvitarhanhoidon harrastajalle. 4. painos. Porvoo: Werner Söderström Osakeyhtiö.

Louhi nro 41, 11.04.1894.

https://digi.kansalliskirjasto.fi/sanomalehti/binding/530689?page=2.

Luettelo Kuopion kaupungin kansankirjaston kirjoista. 1.1.1873. Kansalliskirjaston digitaaliset aineistot. https://digi.kansalliskirjasto.fi/teos/binding/1975970?page=1.

Luettelo Rauman lainakirjaston kirjoista, alkukirjainten johdolla. W. 1873. 1.1.1873. https:// digi.kansalliskirjasto.fi/teos/binding/1975937?page=1.

Martin, Tiina. 2016. Aseman puistossa: Puistoja, pihoja ja puutarhoja rautatieasemilla. Vihti: Aurinko Kustannus. 
Mikkola, Kati. 2009. Tulevaisuutta vastaan: Uutuuksien vastustus, kansantiedon keruu ja kansakunnan rakentaminen. Helsinki: Suomalaisen Kirjallisuuden Seura.

Mäki-Kuutti, Anna-Maria ja Sinikka Torkkola. 2014. "Tarkkuuskello ja höyrykone: Terveysoppaat sukupuoleen kasvattajina". Kasvatus \& Aika 8(1): 37-54. https://journal. fi/kasvatusjaaika/article/view/68566/29848.\%20

Männistö, Tiina. 2003. Haluathan tulla todelliseksi naiseksi? Naisruumiin tuottaminen Suomessa ilmestyneissä nuoren naisen oppaissa 1890-1972. Turku: Turun yliopisto.

Niemelä, Jari. 1996. Lääninlampureista maaseutukeskuksiin: Maaseutukeskusten ja niiden edeltäjien maatalousneuvonta 1700-luvulta 1990-luvulle. Helsinki: Suomen Historiallinen Seura ja Maaseutukeskusten liitto.

Niemelä, Jari. 2008. Talonpoika toimessaan: Suomen maatalouden historia. Helsinki: Suomalaisen Kirjallisuuden Seura.

Nieminen, Hannu. 2001. Sata vuotta eläinten puolesta: Kertomus Suomen Eläinsuojeluyhdistyksen toiminnasta 1901-2001. Helsinki: Suomen eläinsuojeluyhdistys.

Nieminen, Hannu. 2006. Kansa seisoi loitompana: Kansallisen julkisuuden rakentuminen Suomessa 1809-1917. Tampere: Vastapaino.

Ojanen, Eero. 2014. Valoa kansalle: 140 vuotta suomalaista sivistystyötä. Helsinki: Kansanvalistusseura.

Ollila, Anne. 1993. Suomen kotien päivä valkenee... Marttajärjestö suomalaisessa yhteiskunnassa vuoteen 1939. Helsinki. Suomen Historiallinen Seura.

Ollila, Anne. 2000. Aika ja elämä: Aikakäsitys 1800-luvun lopussa. Helsinki: Suomalaisen Kirjallisuuden Seura.

Parvela, A. A. 1930. Oulun läänin viljelyskasvit, Niiden historia ja nykyinen levinneisyys: I Yleinen osa. Helsinki: Vanamo.

Peltola, Jarmo. 2008. Lama, pula ja työttömyys: Tamperelaisperheiden toimeentulo 1928-1938. 1930-Iuvun lama teollisuuskaupungissa II. Tampere: Tampere University Press. http:// urn.fi/urn:isbn:978-951-44-7267-1.

Piirainen, Marjukka. 2016. "Puutarhapuhetta ja puheen tulkintaa: Ammatillinen tieto kulttuurintutkijan tukena."Teoksessa Etnologinen tulkinta ja analyysi. Kohti avoimempaa tutkimusprosessia, toimittaneet Tytti Steel ja Jukka Jouhki, 165-199. Helsinki: Ethnos ry.

Piirainen, Tiina. 2013. Itsekuria ja idealismia: Vegetarismi Suomessa vuosina 1900-1929. Suomen ja Skandinavian historian pro gradu -tutkielma. Oulun yliopisto. http://jultika. oulu.fi/Record/nbnfioulu-201303191111.

Puutarha, 1.2.1908, nro 2. https://digi.kansalliskirjasto.fi/aikakausi/binding/931382?page=16.

Puutarha, 1.1.1928, nro 1, s. 14. https://digi.kansalliskirjasto.fi/aikakausi/binding/931624?page=14.

Pulkkinen, Tuija ja Antu Sorainen (toim.). 2011. Siveellisyydestä seksuaalisuuteen: Poliittisen käsitteen historia. Helsinki: Suomalaisen Kirjallisuuden Seura.

Päivärinne, Tiina. 2010. Luonto, tiede ja teknologia: Kansanvalistuksen Suomi-kuva 1870-1920. Helsinki: Suomen Tiedeseura.

Rantala, Heli. 2013. Sivistyksestä sivilisaatioon: Kulttuurikäsitys J. V. Snellmanin historiallisessa ajattelussa. Turku: Turun yliopisto.

Riksarkivet. "Pehr Olof Emanuel Eneroth." https://sok.riksarkivet.se/Sbl/Mobil/Artikel/16103. 
Ross, Stephanie. 2006. "Paradoxes and Puzzles: Appreciating Gardens and Urban Nature." Contemporary Aesthetics 4. http://hdl.handle.net/2027/spo.7523862.0004.009.

Ruoff, Eeva. 2001a. Vanhoja suomalaisia puutarhoja. Helsinki. Otava.

Ruoff, Eeva. 2001b. "Schalin, Bengt." Kansallisbiografia-verkkojulkaisu. Studia Biographica 4. Helsinki: Suomalaisen Kirjallisuuden Seura. http://urn.fi/urn:nbn:fi:sks-kbg-005004.

Ruoff, Eeva. 2007."Smirnoff, Alexandra."Kansallisbiografia-verkkojulkaisu. Studia Biographica 4. Helsinki: Suomalaisen Kirjallisuuden Seura. http://urn.fi/urn:nbn:fi:sks-kbg-004698.

Ruoff, Eeva. 2006. "Pöyhönen, Nora." Kansallisbiografia-verkkojulkaisu. Studia Biographica 4. Helsinki: Suomalaisen Kirjallisuuden Seura. http://urn.fi/urn:nbn:fi:sks-kbg-005003.

Räisänen, Arja-Liisa. 1995. Onnellisen avioliiton ehdot: Sukupuolijärjestelmän muodostumisprosessi suomalaisessa avioliitto- ja seksuaalivalistusoppaissa 1865-1920. Helsinki: Suomen Historiallinen Seura.

Saelan, Thiodolf. 1916. Finlands botaniska litteratur till och med år 1900. Helsinki: Acta Societatis pro Fauna et Flora Fennica; 43. https://helda.helsinki.fi/handle/10138/16107.

Salmela, Ulla. 2001. "Varhaiset siirtolapuutarhat Suomessa." Teoksessa Hortus Fennicus: Suomen puutarhataide, toimittaneet Maunu Häyrynen, Taneli Eskola, Satu Frondelius ja Pekka Leskinen, 114-118. Helsinki: Viherympäristöliitto ry ja Puutarhataiteen seura ry.

Salmi, Hannu. 2000. "Onko tuoksuilla ja äänillä menneisyys? Aistien historia tutkimuskohteena." Tiede \& edistys 25(1): 52-60.

Satakunta no 44, 30.10.1875.

Savikko, Sari. 2006. Isoäidin puutarhavuosi: Neuvoja joka kuukaudelle. Helsinki: Helmi Kustannus.

Simonen, Seppo. 1953. Maatalouskerholiitto 1928-1953. Helsinki: Maatalouskerholiitto ry.

Simonen, Seppo. 1961. Suomen puutarhatalouden historia. Helsinki: Puutarhaliitto.

Sinnemäki, Aino. 1991. "'Kun herra maksaa laskun, katselkaa muualle': Sadan vuoden tapasuositukset Suomessa." Sosiologia 28(3): 176-191.

Sulkunen, Irma. 1986. Raittius kansalaisuskontona: Raittiusliike ja järjestäytyminen 1870-luvulta suurlakon jälkeisiin vuosiin. Helsinki: Suomen Historiallinen Seura.

Svanberg, Ingvar. 2011. Folklig botanik. Stockholm: Dialogos.

Svensk Trädgård. Luettu 13.5.2019. http://www.tradgard.org/svensk tradgard/zonkartan. html.

Tieteen termipankki. Luettu 26.2.2019. http://www.tieteentermipankki.fi/wiki/ Kirjallisuudentutkimus:kirja.

Tavastähti, Elli. 1914. Koululaisen kasvitarhaopas. Helsinki: Otava.

Turpeinen, Oiva. 1985. Kainuun historia II: Väestö ja talous 1721-1982. Kajaani: Kainuun makkuntaliitto.

Turpeinen, Oiva. 1986. Nälkä vai tauti tappoi? Kauhunvuodet 1866-1868. Helsinki: Suomen Historiallinen Seura.

Vihola, Teppo. 1991. Leipäviljasta lypsykarjaan: Maatalouden tuotantosuunnan muutos Suomessa 1870-luvulta ensimmäisen maailmansodan vuosiin. Helsinki: Suomen Historiallinen Seura. 
Virkkunen, Gia. 2010. "Köyhyydestä ei puhuttu, sitä vaan elettiin": Köyhyyden kokemus ja selviytyminen 1930-luvun pula-ajan oloissa Suomen maaseudulla. Helsinki: Suomalaisen Kirjallisuuden Seura.

Vornanen, Jukka. 2018. "'Pettu wanha tuttu': Perinteisen korvikeruokakulttuurin ja jäkäläleipävalistuksen yhteentörmäys." Teoksessa Nälkävuodet 1867-1868, toimittaneet Tuomas Jussila ja Lari Rantanen, 171-197. Helsinki: Suomalaisen Kirjallisuuden Seura.

Voutilainen, Miikka. 2016. Poverty, Inequality and the Finnish 1860s Famine. Jyväskylä: University of Jyväskylä. https://jyx.jyu.fi/handle/123456789/49598.

FM Marjukka Piirainen tekee kainuulaista puutarhakulttuuria käsittelevää väitoskirjaa Itä-Suomen yliopistossa, perinteentutkimuksen oppiaineessa. 